\title{
Cell-Free Protein Synthesis: A Promising Option for Future Drug Development
}

\author{
Srujan Kumar Dondapati ${ }^{1} \cdot$ Marlitt Stech $^{1}$ - Anne Zemella ${ }^{1} \cdot$ Stefan Kubick ${ }^{1,2}$
}

Published online: 20 March 2020

(c) The Author(s) 2020

\begin{abstract}
Proteins are the main source of drug targets and some of them possess therapeutic potential themselves. Among them, membrane proteins constitute approximately $50 \%$ of the major drug targets. In the drug discovery pipeline, rapid methods for producing different classes of proteins in a simple manner with high quality are important for structural and functional analysis. Cell-free systems are emerging as an attractive alternative for the production of proteins due to their flexible nature without any cell membrane constraints. In a bioproduction context, open systems based on cell lysates derived from different sources, and with batch-to-batch consistency, have acted as a catalyst for cell-free synthesis of target proteins. Most importantly, proteins can be processed for downstream applications like purification and functional analysis without the necessity of transfection, selection, and expansion of clones. In the last 5 years, there has been an increased availability of new cell-free lysates derived from multiple organisms, and their use for the synthesis of a diverse range of proteins. Despite this progress, major challenges still exist in terms of scalability, cost effectiveness, protein folding, and functionality. In this review, we present an overview of different cell-free systems derived from diverse sources and their application in the production of a wide spectrum of proteins. Further, this article discusses some recent progress in cell-free systems derived from Chinese hamster ovary and $S f 21$ lysates containing endogenous translocationally active microsomes for the synthesis of membrane proteins. We particularly highlight the usage of internal ribosomal entry site sequences for more efficient protein production, and also the significance of site-specific incorporation of non-canonical amino acids for labeling applications and creation of antibody drug conjugates using cell-free systems. We also discuss strategies to overcome the major challenges involved in commercializing cell-free platforms from a laboratory level for future drug development.
\end{abstract}

\section{Introduction}

Proteins whose functionality is not well characterized form a large percentage of entries in many of the currently available biological databases, including the Protein Data Bank (PDB), and there is a constantly growing demand for reliable and fast synthesis and characterization methods. When it comes to drug discovery, proteins are key components as they can have therapeutic potential themselves (e.g.,

Stefan Kubick

stefan.kubick@izi-bb.fraunhofer.de

1 Fraunhofer Institute for Cell Therapy and Immunology (IZI), Branch Bioanalytics and Bioprocesses (IZI-BB), Am Mühlenberg 13, 14476 Potsdam, Germany

2 Faculty of Health Sciences, Joint Faculty of the Brandenburg University of Technology Cottbus-Senftenberg, The Brandenburg Medical School Theodor Fontane and the University of Potsdam, Potsdam, Germany antibodies, coagulation factors, hormones, growth factors, enzymes, and antimicrobial peptides), but also because they could serve as drug targets for diverse diseases (as ion channels, receptors, enzymes, and transporters, for example) [1-7]. A large proportion of approved pharmaceutical drugs target human proteins. Beyond that, protein-based therapeutics, such as antibody-drug conjugates, represent a significant percentage of total drug molecules currently approved. They are poised to grow further with increased gene expression technology, improved protein engineering, and refined bioinformatics tools. Some proteins are very difficult to express in traditional cell-based systems and this can hamper our ability to define the mechanism of action and structure-function relationship of the individual protein, knowledge which aids the development of drugs targeting these proteins [1-4].

Generally, to exploit and fine-tune the structural and functional characteristics of a protein, it needs to be expressed and purified with high quality by using 


\section{Key Points}

Cell-free protein synthesis has the potential to become an alternative method for the rapid and highly parallel expression of a diverse range of proteins.

Cell-free systems utilize the translation machinery of the cells, bypassing the constraints of the cell membrane and thus offer openness and configurational flexibility even for the synthesis of difficult-to-express proteins.

In comparison to traditional approaches, cell-free systems can be time-saving, from initial synthesis to downstream applications.

recombinant expression technology. Traditionally, Escherichia coli-based systems were widely used for the production of recombinant proteins due to simplicity in preparation and operation, and cost effectiveness. As a result, broad research and standardization from several years was performed using $E$. coli-based expression systems, resulting in their often-cited utilization as a state-of-the-art protein expression system [8]. For complex therapeutic proteins, membrane proteins (MPs) originating from humans, and virus-like proteins (VLPs), mammalian expression systems fulfill all the requirements like post-translational modifications (PTMs), cofactors, and chaperones for correct folding and efficient production. However, batch-tobatch variation in cell culture may be a source of process variation. Additionally, overexpression of MPs might be toxic for the cultivated cells, resulting in cell death or truncated and misfolded proteins [9].

Ideally, synthesized proteins are functionally folded and exhibit appropriate PTMs. Due to the lack of extensive research and low yields in recombinant protein expression, many MPs are not yet crystallized, thus limiting the computer-aided drug discovery efforts. Due to the growing demand for the production of protein biologics and drug discovery targeting proteins, alternative strategies for protein synthesis should be developed. New expression technologies where proteins can be expressed in a simple way and which allow high throughput screening of different reaction conditions, different genes, and different supplements in a cost-effective manner are extremely important for future drug development. In this review, we give an overview of recent advances in cell-free (CF) synthesis platforms and their diverse applications. Additionally, we focus on human and therapeutic proteins produced by different types of CF systems and how these CF protein synthesis (CFPS) methods can further play a prominent role in future drug development.

\section{Cell-Free Protein Synthesis Systems}

CFPS systems use crude cell extracts prepared from cells of choice by lysis followed by many steps of washing to remove the cell debris and genomic DNA $[10,11]$. These cell extracts can be stored at $-80{ }^{\circ} \mathrm{C}$ for years and can be used by thawing just before the reaction. Such extracts contain all the principal components necessary for transcription and translation, such as aminoacyl-tRNA synthetase (AAS), ribosomes, and factors necessary for elongation, initiation, and transcription. Protein synthesis can be realized by combining cell extracts with necessary substrates like amino acids, energy substrates, DNA, cofactors, salts, and nucleotides. Depending on the biochemical properties of the protein and its end application, the appropriate CF system can be selected. CFPS is a fast protein production system since it does not require transfection or cell culture and lacks cell viability constraints. Due to its openness, CFPS platforms offer additional advantages when compared with cell-based expression methods. A comparative analysis of CF and cellbased approaches is shown in Table 1.

For complex proteins, eukaryotic CF systems are ideal as they contain the endogenous microsomes derived from the endoplasmic reticulum (ER), enabling co-translational translocation of proteins and ER-based PTMs [10, 11, 18, 19]. There has been a constant improvement in the quality of lysate preparation, system optimization, linear templatebased protein synthesis, and reduction of process costs, which has led to the preparation of cost-effective systems suitable for commercial purposes.

\section{Cell-Free Systems}

A general scheme of CF protein production is depicted in Fig. 1. CFPS platforms are based on either prokaryotic or eukaryotic origin. Among the prokaryotic CF systems, extracts based on E. coli are regularly used and are available commercially for CFPS of a diverse range of proteins. Very recently, CF systems based on Bacillus subtilis [32], Pseudomonas putida [33], Streptomyces [34], and Vibrio [12] have been optimized well at the laboratory level due to the ease of preparation of $\mathrm{CF}$ lysates. A wide range of detailed protocols is currently available for the preparation of E. coli-based lysates. Among the eukaryotic CF systems, extracts based on rabbit reticulocyte lysate (RRL), wheat germ, insect Spodoptera frugiperda 21 (Sf21), Chinese hamster ovary (CHO), and cultured human cells are regularly used. An increasing number of eukaryotic $\mathrm{CF}$ systems have so far reached technical maturity and become commercially available. 


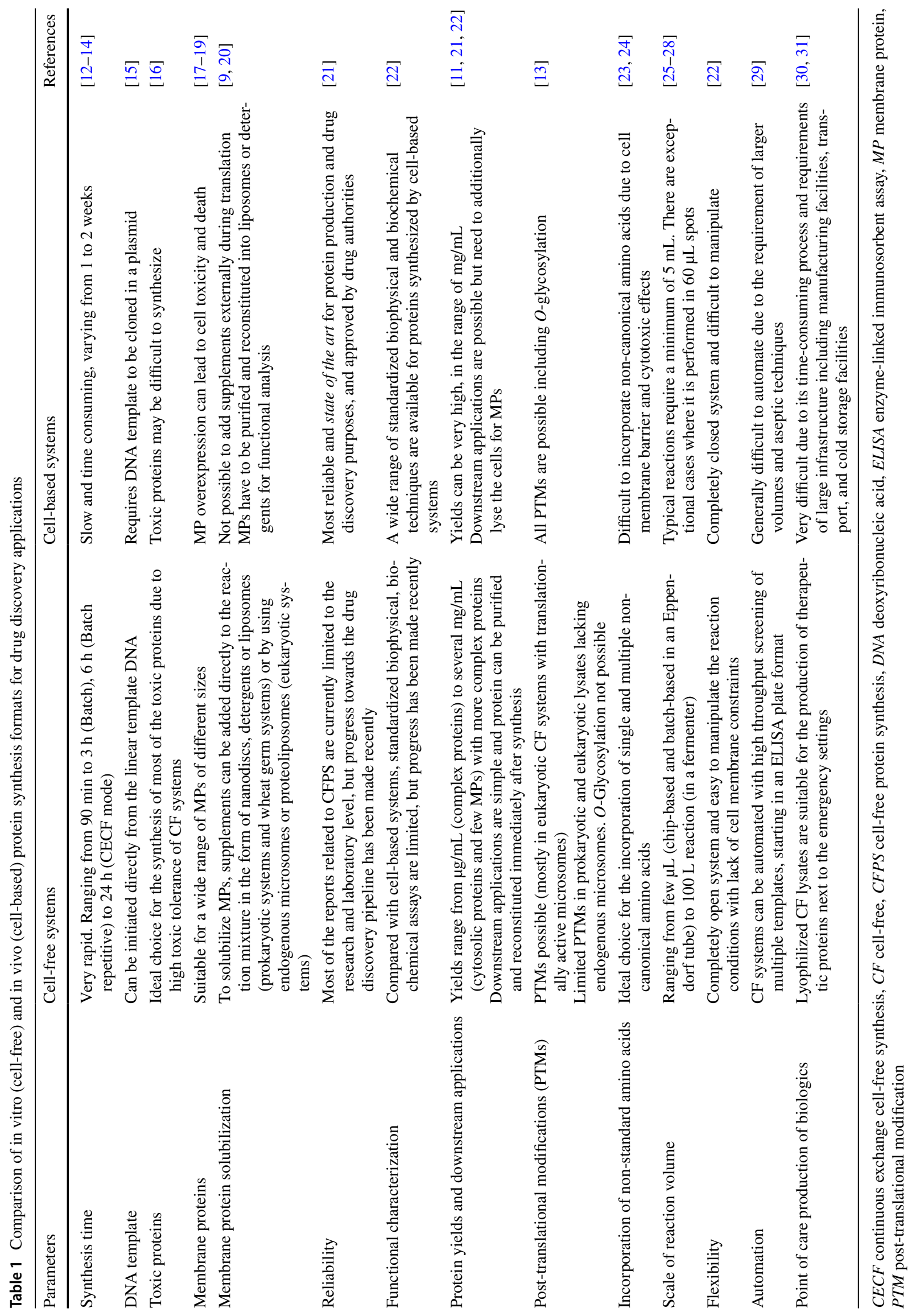




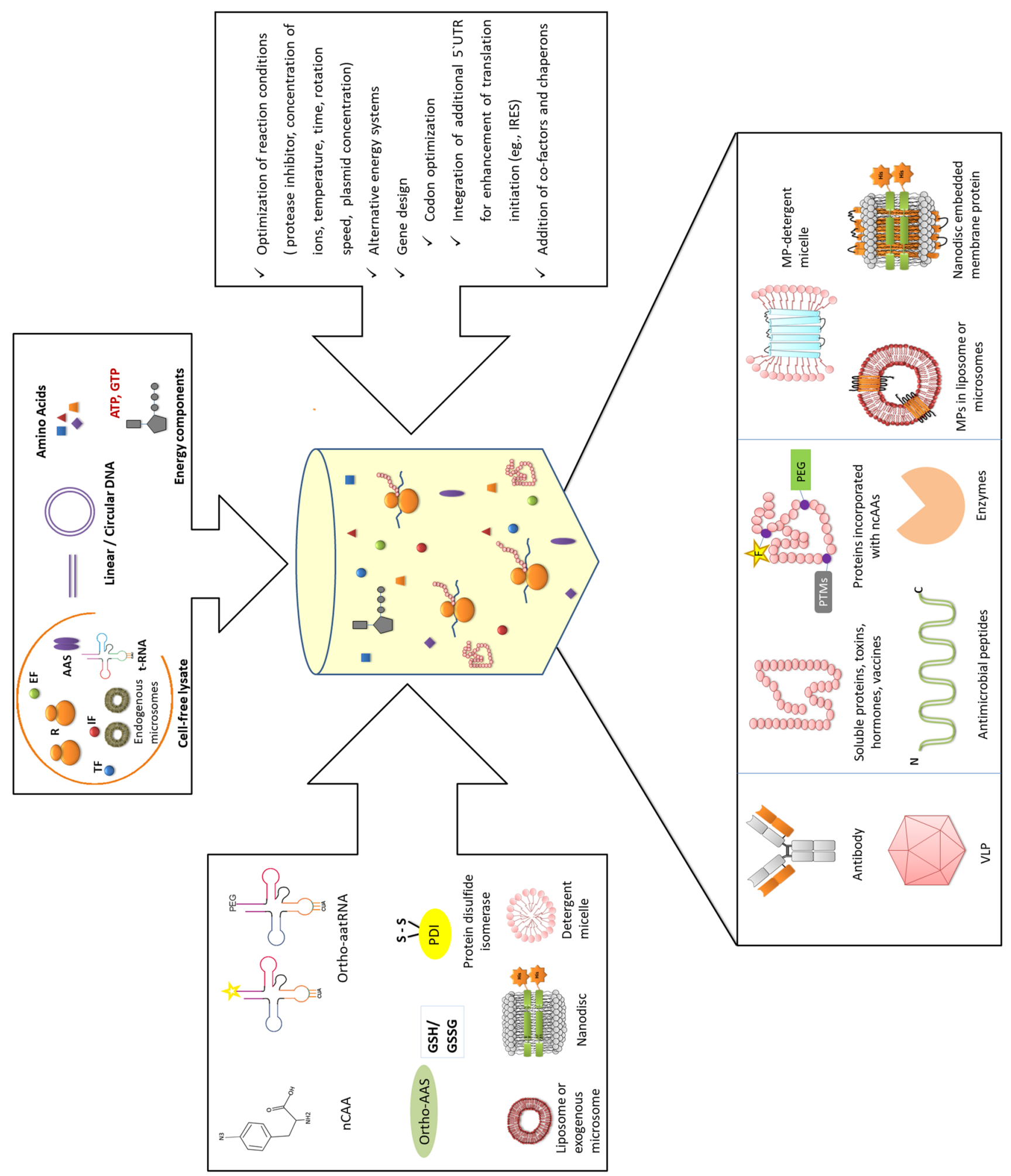


4 Fig. 1 General scheme depicting the overall process of cell-free protein production. aatRNA aminoacyl-tRNA, AAS aminoacyl-tRNA synthetase, ATP adenosine triphosphate, $E F$ elongation factor, $G S H$ glutathione, GSSG glutathione-disulfide, GTP guanosine-5'-triphosphate, IF initiation factor, IRES internal ribosome entry site, $M P$ membrane protein, $n C A A$ non-canonical amino acid, $P D I$ protein disulfide isomerase, $P E G$ polyethylene glycol, $P T M$ post-translational modification, $R$ ribosomes, $t-R N A$ transfer RNA, $T F$ transcription factor, $U T R$ untranslated region, $V L P$ virus like particle

Recently, several eukaryotic CF extracts based on Tobacco [35], Leishmania [36], Neurospora [37], yeast cells [38], and human blood cells [39] were characterized and optimized for a limited number of proteins at the laboratory level. There is a growing trend in the development of novel CF platforms for taking advantage of the genetic tools available in the literature and the abundant literature available on the in vivo expression of proteins.

\subsection{Prokaryotic Cell-Free Platforms}

Prokaryotic CF systems based on E. coli are most commonly used for protein production towards drug development due to their simplicity and a vast literature available on the utilization of these cells. Protein synthesis starts with crude cell extracts prepared from $E$. coli cells that contain the translation machinery along with all the essential components required for translation. A modified and reconstituted $\mathrm{CF}$ synthesis system known as the PURE system (protein synthesis using recombinant elements), where all the components of the translation machinery are purified and added individually along with the DNA template to produce the protein, has been reported [40]. This is a highly controlled system compared with crude extract methods. A major advantage of the PURE system is that protein factors participating in the initiation, elongation, and termination of the protein synthesis process are identified and can be adapted individually to the CF system's requirements. Although the naturally occurring PTM machinery is not available in the E. coli lysates, recently proteins with $N$-glycosylation were synthesized by using $E$. coli extracts enriched with glycosylation components, including oligosaccharyltransferases (OSTs) and lipid-linked oligosaccharides (LLOs) [41]. Using release factor (RF1) deficient $E$. coli lysates, proteins were phosphorylated by incorporation of non-canonical amino acids, which will be addressed in a later part of this review [42].

\subsection{Eukaryotic Cell-Free Platforms}

Due to a constantly growing demand for more complex proteins of pharmaceutical value, CF systems based on eukaryotic lysates have been developed to produce highquality proteins. CF systems based on wheat germ lysates (WGL) are among the most popular eukaryotic platforms due to their capacity to produce eukaryotic proteins with high yields [43]. CFPS based on WGL have been used frequently for the discovery of novel vaccine candidates as well as for producing several proteins of high quality for structural analysis. Despite the high yields and quality of the lysate, this system does not offer all the PTMs like glycosylation and does not support the solubilization of complex MPs [13]. In the case of wheat germ and RRL, there are no translationally active endogenous microsomes present in the system. In the case of RRL, exogenous microsomes are typically supplied from the canine pancreas for protein translation [13, 44]. It is quite laborious and difficult to enrich RRLs with heterologous microsomes.

$\mathrm{CF}$ systems derived from cultured insect $(S f 21)$ cells represent the most popular eukaryotic-based approach for synthesizing a wide variety of proteins. Sf21 lysates contain translationally active endogenous ER membranes, thereby supporting the signal peptide-mediated translocation of proteins across the membrane, and further provides functions such as signal peptide cleavage, post-translational modifications like $N$-glycosylation, and lipid modification $[13,14$, 45].

CHO cell-based expression is well established and is approved for the large-scale synthesis of several biologics by the FDA because it undergoes human-compatible PTMs. Nearly $70 \%$ of the approved mammalian therapeutic proteins are currently expressed in $\mathrm{CHO}$ cells. However, these cells have limitations when it comes to difficult-to-express proteins like overexpression of complex MPs, toxic proteins, and multi-subunit proteins as discussed above. CF systems based on $\mathrm{CHO}$ lysates are evolving as an alternative strategy for the expression of difficult-to-express proteins [13, 17-19, 46]. Apart from many general advantages of CF systems, CHO-based CF systems retain most of the features of $\mathrm{CHO}$ cells while being more flexible due to the lack of cell membrane boundaries. CHO-based lysates harbor endogenous microsomal vesicles enabling translocation of transmembrane proteins and secretory proteins. Furthermore, PTMs of de novo synthesized MPs, such as glycosylation, are possible using $\mathrm{CHO}$ lysate. Thus, using $\mathrm{CHO}$ cell lysate for CFPS has a potential value and enables new opportunities, in particular, the high-yield production of pharmaceutically relevant MPs [13, 17-19]. There is a significant increase in the number of publications based on CHO lysates for CFPS. Table 2 compares different CF systems and their advantages and limitations with some selected examples. 


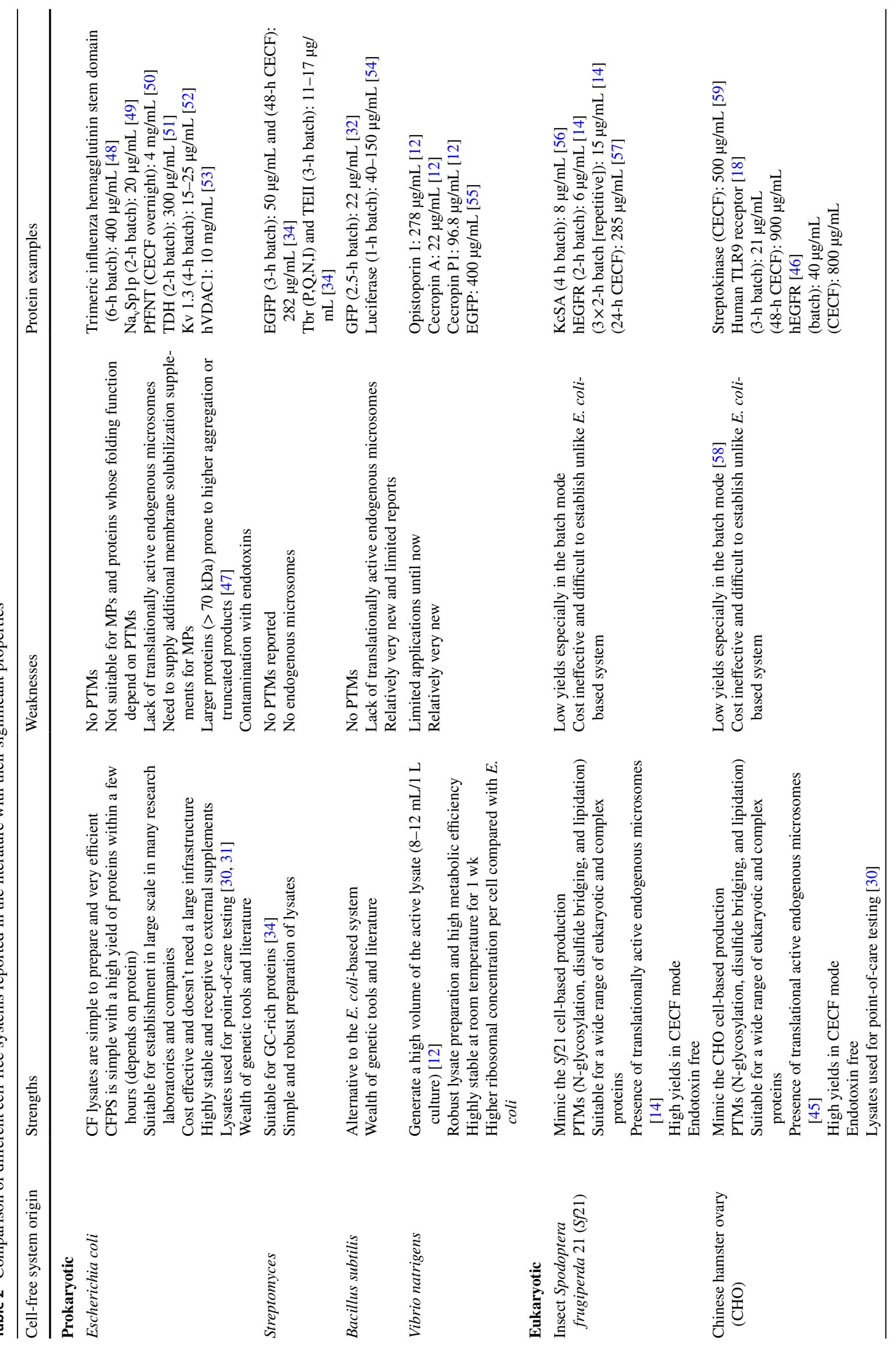




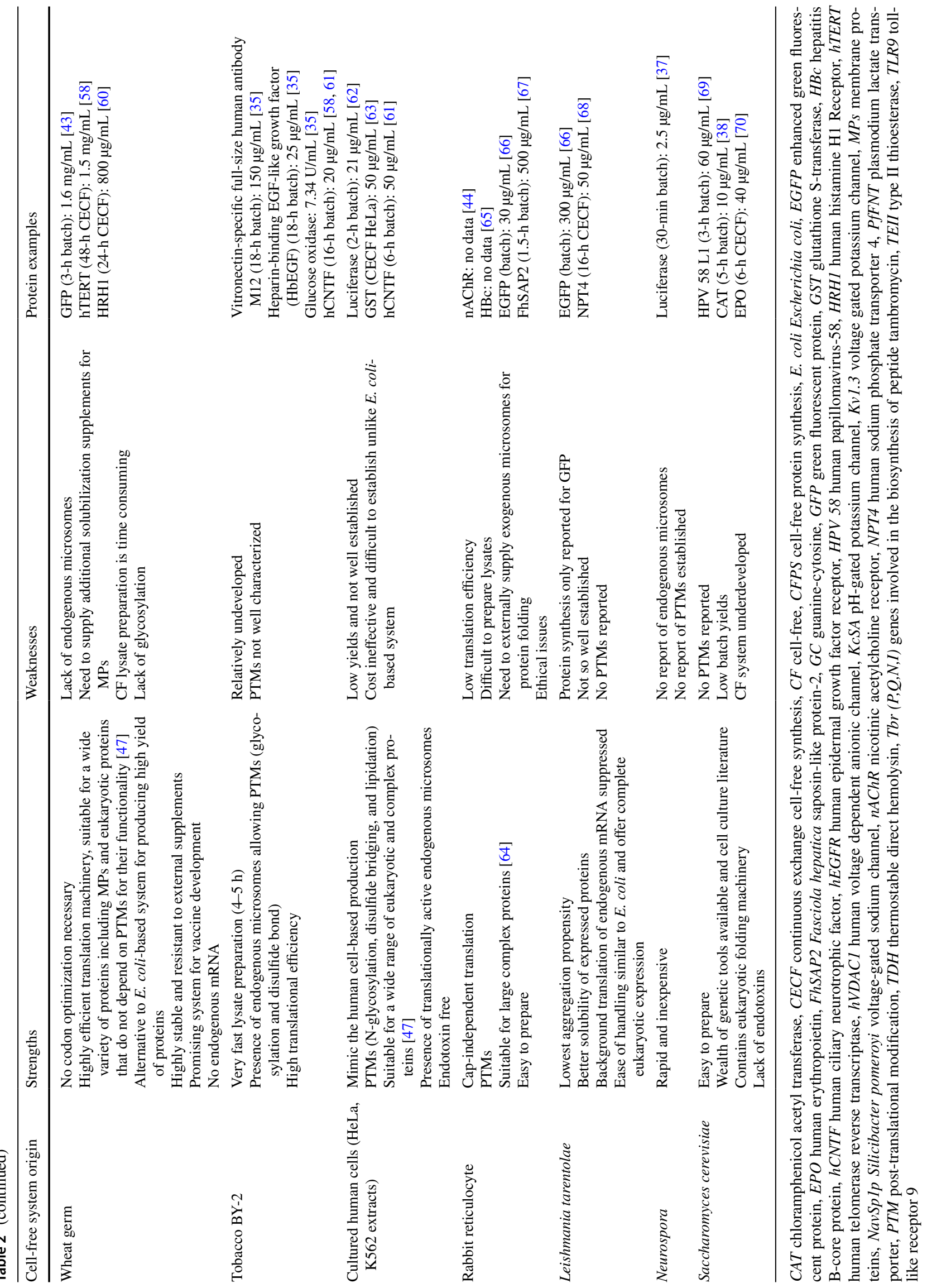




\section{Cell-Free Protein Synthesis Reaction Formats}

CFPS can be performed in different formats. The batchbased format is the most commonly used method both in the prokaryotic and eukaryotic systems. This method is relatively fast and cheap, and synthesis can be performed within 1.5-3 hours depending on the system. E. coli-based systems can provide protein yields ranging from $100 \mu \mathrm{g} /$ $\mathrm{mL}$ to $2-3 \mathrm{mg} / \mathrm{mL}$. Although the yields from batch-based eukaryotic systems are comparatively low, MPs are automatically incorporated into microsomal membranes and the functionality can be addressed immediately after the synthesis [62]. For researchers who would like to further scale up the protein yields via batch-based eukaryotic systems, a repetitive batch-based synthesis format has been proposed where the microsomes incorporating the MP of interest generated in an initial synthesis reaction can be added to a fresh CF synthesis reaction that has been depleted of its microsomes $[19,45]$.

Another popular CF synthesis format that has been used for a rapid increase in the protein yields is the so-called continuous exchange cell-free synthesis platform (CECF). In this format, a semi-permeable dialysis membrane separates the reaction chamber and a feed chamber and thereby a feed chamber provides the fresh reaction components and enriches the reaction chamber. In exchange, the inhibitory components accumulated during the reaction are removed $[14,17,18,46]$. Typically, the CECF format prolongs the reaction time and increases the protein yields. Until now, the $\mathrm{CECF}$ format has been used to increase the protein yield by multiple fold, and is widely used as CF platforms (Table 2).

\section{Parameters Influencing Cell-Free Protein Production}

This section highlights some of the key parameters that might influence the protein production using CF lysates.

\subsection{Gene Design}

Designing synthetic DNA and sequence manipulation for $\mathrm{CF}$ synthesis by adding regulatory elements plays a significant role in high-yield protein production. In eukaryotic CF systems, initiation factors (IFs) in particular limit the initiation of protein synthesis, thereby leading to low protein yields. One alternative is to use internal ribosome entry site (IRES) elements found in the 5 '-untranslated region (5'UTR) of the different viral genomes upstream of the start codon for cap-independent translation initiation [14, 18, 62]. IRES elements from three different viral sources were compared for their translational efficiency in $S f 21, \mathrm{CHO}$, and human leukemia K562 CF lysates. The IRES from the cricket paralysis virus (CrPV) typically increased protein yields by a factor of 3-5 [62]. Inserting the CrPV-IRES into the corresponding vector upstream of the epidermal growth factor receptor (EGFR) gene, and using the CECF reaction format, EGFR yields were significantly increased to more than 100-fold compared with batch reaction format without CrPV-IRES [14]. Additionally, replacement of the initiator codon (ATG) to a GCU-codon in combination with the CrPV-IRES resulted in a further improvement of protein expression levels in CHO and K562 CF systems [62]. The vector backbone also plays an important role in CFPS. A detailed study comparing commercially available vectors harboring the luciferase gene in combination with CrPVIRES showed that there is a significant 5-fold increase in protein yield with a change in the vector backbone [19].

Species-independent translational sequences (SITS) are another group of synthetic $5^{\prime}$ UTRs capable of initiating cap-independent translation in multiple prokaryotic and eukaryotic CF systems [66]. Typically, polymerase chain reaction (PCR) products are generated with SITS downstream of the T7 promoter and upstream of the start codon ATG [66]. The 3' hairpin region of the SITS increases the residence time of the preinitiation complex in the vicinity of the start codon [66]. Using L. tarentolae CFPS in the presence of genes encoding 58 Rab encoding variable fragments in combination with a universal SITS, nearly a full complement of human Rab GTPases were produced with a yield of around $30 \mu \mathrm{g} / \mathrm{mL}$ [36]. Similarly, EGFP with a yield of around $300 \mu \mathrm{g} / \mathrm{mL}$ [66], and an active multisubunit enzyme heterodimeric farnesyl transferase (FTase) [36] were synthesized using the L. tarentolae CFPS [36].

Codon optimization is another important parameter that plays a crucial role in increasing the expression yields of proteins. Codon optimization has been shown to influence the translation efficiency of several proteins [71]. By taking advantage of the CF lysates derived from $N$. crassa and $S$. cerevisiae, transcription and translation reactions were uncoupled for ribosome profiling, which provided strong biochemical evidence that codon optimization enhances the rate of translational elongation, thereby affecting the ribosome traffic on the mRNA [72]. On the one hand, codon optimization usually improves protein yields, but on the other hand, it was shown that faster translation rates might negatively affect the protein folding and function of the individual protein $[72,73]$. This problem often cannot be solved even by altering the tRNA population in the case of CFPS.

The addition of anti-spliced leader oligonucleotide to $L$. tarentolae cell extracts suppressed the translation of endogenous $L$. tarentolae mRNAs, thus increasing the translation efficiency of exogenously supplied mRNA [65]. Using the ER-specific signal sequence of honeybee melittin (melittin 
signal peptide) instead of the native signal peptide increased the translocation of synthesized proteins such as WNT proteins, single-chain antibody variable fragments, and the hTLR9-ectodomain into microsomes in the case of $S f 21$ and CHO-based CF systems [18, 59, 74, 75].

\subsection{Reaction Conditions}

Iterative optimization processes are required to develop highyield CFPS. Factors that influence both protein quality and quantity include reaction temperature, reaction time, plasmid concentration, salt concentration, $\mathrm{T} 7$ polymerase, and other supplements. The influence of these factors on the synthesis rates is also protein specific. Very recently, CFPS of human toll-like receptor protein (hTLR9) in CHO-based lysates has been reported by using a CECF method with high yields of around $0.9 \mathrm{mg} / \mathrm{mL}$. By increasing the temperature from 27 to $30{ }^{\circ} \mathrm{C}$, the protein yields were increased by almost $50 \%$. Stable monitoring and maintenance of $\mathrm{pH}$ throughout the entire $\mathrm{CF}$ reaction along with sufficient adenosine triphosphate (ATP) supply are essential for efficient and maximum yield protein production. By using amino acid decarboxylase, the $\mathrm{pH}$ is controlled throughout the $\mathrm{CF}$ reaction [76].

\subsection{Influence of External Supplements}

Supplementation of chaperones influences the functional folding of many proteins. Supplementation of chaperones such as GroES/EL and DnaK/DnaJ/GrpE in prokaryotic $\mathrm{CF}$ systems was used to increase the yield and solubility of colicin M from 16 to $100 \%$, resulting in enhanced cellkilling activity [77]. Li et al. demonstrated that by using CFPS based on wheat germ extracts, expression of J-domain containing chaperone proteins (DNAJB12 and DNAJB14) along with potassium channels plays a critical role in the folding, stabilization, and tetramerization of $\mathrm{K}+$ channels [78]. Ion concentrations (potassium and magnesium) in the $\mathrm{CF}$ reaction have a significant effect on protein production. In the case of CHO-based CECF reactions, an increase in the magnesium ion $\left(\mathrm{Mg}^{2+}\right)$ concentration from 3.9 to $22.5 \mathrm{mM}$ led to a 3.9-fold increase in EGFR yield [46].

For efficient regeneration of ATP, several methods have been developed in CF systems. In prokaryotic systems, compounds like phosphoenolpyruvate (PEP), glucose + glutamate decarboxylase, glucose-6-phosphate, fructose1,6-biphosphate, acetyl phosphate, maltodextrin, and creatine phosphate are widely used as energy sources [79]. In eukaryotic CF systems, a combination of creatine phosphate and creatine kinase is typically used for energy regeneration. Apart from these, phosphoglycerate (B. subtilis), and polyphosphate are used in CF systems [80, 81].

\section{Applications of Cell-Free Systems}

CF systems have evolved over the last decade from their use as a prototype method in research laboratories to commercial and large-scale applications. In this section, the utility of CF systems in MP synthesis, antibody production, vaccine development, protein labeling, and antimicrobial peptide synthesis are addressed.

\subsection{Cell-Free Systems for the Synthesis of Membrane Proteins}

MPs are structurally and functionally diverse, and constitute $30 \%$ of the proteins encoded in the human genome. Drugs targeting MPs such as ion channels, transporters, and G-protein coupled receptors (GPCRs) represent 12 out of the top 20 global revenues in the pharmaceutical industry [3]. Due to the presence of transmembrane domains, ranging from 1 to 24 , these proteins are highly hydrophobic and are very challenging to express by traditional cell-based systems. Expression of human proteins in heterologous cellular hosts is very much limited due to the difference in their lipid composition, which can prevent the MPs from attaining maximum functionality [9]. Synthesis of MPs by cell-based methods often leads to cytotoxicity, aggregation, and improper folding [9]. To analyze MP functionality, the protein needs to be folded properly and in the appropriate hydrophobic environment. CF systems derived from prokaryotic, as well as eukaryotic lysates lacking endogenous microsomes, require specific supplements for the solubilization of MPs in the form of detergents, nanodiscs, or liposomes. Non-ionic and zwitterionic detergents are commonly used as supplements in the majority of CFPS reactions for the solubilization of MPs during their production. Detergent-solubilized MPs can be either used directly for functional analysis or may be reconstituted into liposomes by mixing with artificial lipids followed by detergent removal $[9,82,83]$.

Alternatively, nanodiscs (NDs) and liposome-based reconstitution are detergent-free strategies where NDs and liposomes, prepared and characterized externally, could be supplemented directly into the reaction mixture for the reconstitution [9, 84]. A detailed review of the CF synthesis of MPs and the usage of solubilization supplements for isolation and functional analysis is presented in the literature [9]. Some of the advantages of NDs are easy purification and flexibility in using different lipids and membrane scaffold proteins for creating different sizes, and their availability as monodisperse and homogenous NDs. Nonetheless, NDs have their limitations, particularly when working with a protein whose functionality depends on its orientation and also working with transporter proteins. Liposome-based reconstitution covers the limitations of the NDs, but the separation 
of liposomes after the $\mathrm{CF}$ reaction is quite challenging and often suffers from disruption due to osmotic instability. Further, such passive reconstitution strategies do not offer the advantages of post-translational modifications within native membranes and are limited for MPs whose function does not depend on active translocon-based translation.

$\mathrm{CF}$ systems derived from eukaryotic lysates equipped with endogenous microsomes (e.g., $S f 21, \mathrm{CHO}$, cultured human cells, and Tobacco-BY2) satisfy all the necessary requirements for proper folding of MPs. The microsomes offer a native environment and intact translocon machinery for a proper embedment and folding of MPs [13, 18, 19, 45, $46,51,59]$. There are continuing efforts in analyzing the functionality of microsomal reconstituted MPs, indicated by a good number of publications reporting on this reconstitution strategy, which should help the pharmaceutical industry to develop more dynamic drug screening assays involving MPs [9, 46, 83]. Here we present recent works on ion channels, transporters, and GPCRs, which constitute more than $40 \%$ of the major drug targets in the pharma industry [85].

\subsubsection{Ion Channels and Transporters}

Ion channels constitute approximately $19 \%$ of all currently existing human drug targets and play a crucial role in diverse physiological processes involving cell excitability, neuronal transmission, metabolism, sensory transduction, cognition, and electrolyte homeostasis. Transporters mediate the translocation of a variety of substrates across biological membranes [86]. The solute carrier (SLC) family is the largest class of transporters and is implicated in metabolic conditions and diseases, and in the transport of drugs. These proteins typically have 9-12 transmembrane domains and are difficult to express by traditional methods $[2,9,50,87]$. SLC transporters are an emerging drug target class and the molecular target of several approved inhibitor drugs [2]. Despite this, these classes of proteins remain largely unexplored in recent years due to the high costs involved and lack of proper expression methods $[9,53]$. Table 3 highlights some of the selected publications using CF methods for synthesis, reconstitution, and functional analysis of ion channels and transporters.

The most widely used method of reconstitution for functional analysis is detergent-based reconstitution into liposomes or passive integration of MPs into liposomes and NDs. The majority of the functional assays were performed with PLBE in the case of ion channels and substrate uptake assays in the case of transporters.

\subsubsection{G-Protein Coupled Receptors (GPCRs) and Drug Discovery in Cell-Free Systems}

GPCRs transduce extracellular stimuli to the inside of cells, after activation by a variety of different molecules such as neurotransmitters, hormones, odorants, and peptides, thereby triggering several signal transduction cascades. The involvement of GPCRs in almost all processes in living cells has resulted in significant pharmaceutical interest in this protein class, and the development of robust and high-throughput-suitable assays for the discovery of novel ligands and drugs targeting these proteins. In principle, the screening of ligands can be performed in whole-cell assays by measuring a downstream signaling event, or in $\mathrm{CF}$ assays, which are decoupled from the living organism. Usually, these decoupled methods are preferable for high-throughput screenings, as they are easy to handle and therefore amenable for automation and downsizing. These parameters can be well combined with CFPS. An automated CF synthesis procedure for the production of different MPs is already reported [97]. This procedure might be further expanded for the parallel analysis and identification of molecules that target different GPCRs. To date, only a few studies have analyzed in detail the activity of receptors produced by $\mathrm{CF}$ systems. The main reason for this is that there are limited well established activity assays. This section addresses possible activity assays that might be transferred to $\mathrm{CF}$ systems in the future.

Radioligand binding assays, the gold standard for identifying binding molecules, are already adapted for GPCRs that have been synthesized in eukaryotic and prokaryotic $\mathrm{CF}$ systems, and demonstrate similar binding affinities in comparison with in vivo produced GPCRs [20, 98-100]. Alternatively, fluorescently labeled ligands can be analyzed by an optical read-out system using eukaryotic CF systems harboring endogenous membrane structures [101]. Nevertheless, for these systems, radiolabeled or fluorescently labeled ligands are required, thereby limiting the analysis mainly to GPCRs with already known ligands. In addition, simple ligand binding assays usually do not differentiate between an agonistic and an antagonistic effect of the bound substance.

In this context, measuring downstream signaling to distinguish between an activating and inhibitory ligand is preferable. One possible method of choice is the receptor-mediated coupling of $\mathrm{G}$ proteins [102]. This early event immediately follows after GPCR activation and is detected by the binding of $\left[{ }^{35} \mathrm{~S}\right] \mathrm{GTP} \gamma \mathrm{S}$ to $\mathrm{G} \alpha$ subunits. This method is not yet established in CF systems but might be transferable assuming the presence of $\mathrm{G} \alpha$ proteins in the eukaryotic lysate. Alternatively, the $\mathrm{G} \alpha$ proteins can be additionally co-synthesized to the target GPCR or directly applied to the reaction based on the open nature of CF systems. After GPCR activation, GTP binding and hydrolysis should be detectable. 
Table 3 Functional ion channels and transporters synthesized using CF systems

\begin{tabular}{|c|c|c|c|}
\hline Protein & Cell-free system & Solubilization/reconstitution & Assessment of functionality \\
\hline $\mathrm{LacY}$ & E. coli $(P U R E)$ & $\begin{array}{l}\text { Liposome reconstitution through Droplet } \\
\text { interface [88] }\end{array}$ & Fluorescence substrate uptake \\
\hline $\mathrm{Kv} 1.1$ and $\mathrm{Kv} 1.3$ & E. coli & Detergent-based reconstitution [89] & Electrophysiology at the droplet interface \\
\hline Kv 1.3 & E. coli & $\begin{array}{l}\text { Detergent-based reconstitution into } \\
\text { liposomes [52] }\end{array}$ & Voltage-sensitive fluorescent dye recording \\
\hline Kv 7 channels & E. coli & Detergent-based reconstitution [90] & Electrophysiology at the droplet interface \\
\hline TDH & E. coli & Direct insertion [51] & PLBE \\
\hline Voltage gated ion channel MVP & E. coli & $\begin{array}{l}\text { Detergent-based reconstitution into } \\
\text { liposomes [82] }\end{array}$ & PLBE \\
\hline LeuT & E. coli & $\begin{array}{l}\text { Detergent-based reconstitution into } \\
\text { liposomes [82] }\end{array}$ & Radioactive substrate uptake assay \\
\hline PfFNT & E. coli & $\begin{array}{l}\text { Detergent-based reconstitution into } \\
\text { liposomes [50] }\end{array}$ & $\begin{array}{l}\text { Dynamic light scattering based transport } \\
\text { assay }\end{array}$ \\
\hline $\begin{array}{l}\text { SLC22 protein family (organic } \\
\text { cation and anion transporter } 1 \text { ) }\end{array}$ & E. coli & $\begin{array}{l}\text { Detergent-based reconstitution into } \\
\text { liposomes [91] }\end{array}$ & Radioactive substrate uptake assay \\
\hline MscL & E. coli & $\begin{array}{l}\text { Detergent-based reconstitution into } \\
\text { liposomes [92] }\end{array}$ & Patch-clamp electrophysiology on liposomes \\
\hline AqpZ & E. coli & $\begin{array}{l}\text { Detergent-based reconstitution into } \\
\text { liposomes }[49,93]\end{array}$ & $\begin{array}{l}\text { Light scattering measurement of water } \\
\text { transport activity }\end{array}$ \\
\hline NavSp1p (Only pore region) & E. coli & $\begin{array}{l}\text { Detergent-based reconstitution into } \\
\text { liposomes [49] }\end{array}$ & PLBE \\
\hline $\begin{array}{l}\text { Connexin } 43 \\
\text { Hemichannels }\end{array}$ & E. coli & $\begin{array}{l}\text { Detergent-based reconstitution into } \\
\text { liposomes [94] }\end{array}$ & PLBE \\
\hline Viral potassium channel Kmpv1 & E. coli & NDs [95] & PLBE \\
\hline $\mathrm{KcSA}$ & $\begin{array}{l}\text { Sf } 21 \\
\text { E. coli }\end{array}$ & $\begin{array}{l}\text { Microsomes [56] } \\
\text { Detergent-based reconstitution into } \\
\text { liposomes/NDs incorporation }[82,84]\end{array}$ & PLBE \\
\hline Aspartate transporter & $S f 21$ & Microsomes/proteoliposomes [87] & Radioactive substrate uptake assay \\
\hline KvAP & $\mathrm{CHO}$ & Microsomes/proteoliposomes [46] & PLBE \\
\hline Ant1p & Wheat germ & $\begin{array}{l}\text { Detergent-based reconstitution into the lipo- } \\
\text { some [96] }\end{array}$ & ATP dependent transport activity \\
\hline hVDAC1 & Wheat germ & $\begin{array}{l}\text { Detergent-based reconstitution into } \\
\text { liposomes [53] }\end{array}$ & PLBE \\
\hline $\mathrm{nAChR}$ & RRL & Microsomes [44] & PLBE \\
\hline B Connexins & RRL & Microsomes [94] & PLBE \\
\hline
\end{tabular}

Antlp adenine nucleotide transporter, AqpZ aquaporin Z, CHO Chinese hamster ovary, ATP adenosine triphosphate, E. coli Escherichia coli, $h V D A C 1$ human voltage-dependent anionic channel, $K c S A \mathrm{pH}$-gated potassium channel, $K v A P$ voltage-gated potassium channel, $K v 1.1$, $K v 1.3$, and $K v 7$ voltage gated potassium channels, $L a c Y$ lactose transporter, $L e u T$ leucine transporter, $M s c L$ mechanosensitive ion channel, $M V P$ a methanococcal voltage-gated potassium channel, nAChR nicotinic acetylcholine receptor, NavSplp Silicibacter pomeroyi voltage-gated sodium channel, $N D s$ nanodiscs, PfFNT plasmodium lactate transporter, PLBE planar lipid bilayer electrophysiology, $R R L$ rabbit reticulocyte lysate, $S f 21$ Spodoptera frugiperda 21, $T D H$ thermostable direct hemolysin

In addition to ligand binding and $\mathrm{G}$ protein coupling, intra- and intermolecular interactions can be visualized by Förster and bioluminescence resonance energy transfer techniques. Different sensor models are known in living cells [103]. The monitoring of intermolecular interactions can be performed as well in CF systems using the already established in vivo models. One model includes the tagging of the C-terminus of a GPCR of interest to a fluorophore (GFP/YFP) and fusing a binding partner such as $\beta$-arrestin to luciferase or a second fluorophore [104]. Upon activation of the GPCR, $\beta$-arrestin binds to the receptor and both tags are in close proximity, resulting in a measurable energy transfer. This model requires active $G$ protein-coupled receptor kinases for the phosphorylation of the $\mathrm{C}$ terminus of the synthesized GPCR to get recognized by $\beta$-arrestins. This requirement has to be analyzed in detail in the individual $\mathrm{CF}$ systems. The second known in vivo model visualized intramolecular changes after agonist and antagonist binding by introducing fluorophores into the third extracellular loop and the $\mathrm{C}$ terminus of different GPCRs. Upon activation, the distance between both fluorophores changes and an alteration in the energy transfer can be measured $[105,106]$. 
Initial experiments to transfer these energy transfer-based sensors were recently performed in CF systems [107]. Both models can be applied to high-throughput analyses.

In summary, the successful CF synthesis of a variety of GPCRs has been demonstrated in recent years and a transfer of these GPCR production systems to a drug discovery format in a high-throughput manner has recently started. In the near future, we might see novel technologies for ligand screenings, thereby utilizing the advantage of the automatization and downsizing capacity of CF systems.

\subsection{From Antibody Discovery to Production}

The gold standard for synthesis, development, and production of antibody-based drugs (based on full-length antibodies) is mammalian cell culture-based expression systems. Although cultivation of mammalian cells is well established and widely used, the development of monoclonal antibodies (mAbs) and antibody-drug conjugates (ADCs) remains time-consuming and challenging. Thus, methods for highthroughput screenings, especially in the early-stage evaluation of antibody candidates, are valuable. In view of this, the use of the CF technology constitutes a promising strategy to shorten the time from antibody discovery to production.

\subsubsection{Antibody Discovery}

Using CF technology, antibodies can be produced in a flexible scale within a couple of hours. Besides the synthesis of individual antibodies, CF technology can be used to display libraries of antibodies. In contrast to phage and yeast display, in vitro CF systems such as ribosome and mRNA display are open, and thus result in higher library sizes. In theory, the size of the library is only limited by the quantity of supplemented mRNA/DNA, the volume of the CF reaction, and the number of ribosomes within the system, resulting in library sizes of $\sim 10^{12-15} / \mathrm{mL}$ CF reaction [108]. In comparison, phage and yeast display exhibit library diversities of $\sim 10^{6}-10^{10}$. Selection technologies such as ribosome display [109], mRNA display [110], and CIS display [111] have been developed based on reticulocyte lysate [110] and E. coli CF systems [109]. These systems focused on smaller antibody fragments because their functionality does not rely on the assembly of multiple polypeptide chains. Nonetheless, recently two groups have succeeded in developing completely CF display technologies that allow the selection of Fab fragments [112]. The challenge to assemble the heavy and light polypeptide chain (HC/LC) of the Fab fragment was approached in different ways. While Sumida et al. succeeded by combining mRNA display based on two mRNA sub-libraries, one encoding $\mathrm{HC}$, the other one encoding LC, with in vitro compartmentalization PCR to link and then amplify HC and LC gene pairs [112], Stafford et al. developed a ribosome display method where they displayed only one of the two Fab chains, while the other one was not presented in display format [113].

\subsubsection{Antibody Production}

Successful synthesis of different antibody formats, including single-chain variable fragments (scFvs), Fab fragments, as well as complete IgGs, has already been shown in $E$. coli [114, 115], Sf21 [10, 116], reticulocyte [110], wheat germ [117], and CHO CF systems [46, 75, 118]. Furthermore, the upscaling of CF reactions to the liter-scale [25, 115] as well as downscaling [119] and high-throughput applications [120] have been demonstrated.

In addition, advances in bioorthogonal reaction chemistries have paved the way to expand the possibilities for ADC development. The site-specific introduction of non-canonical amino acids into a genetically engineered sequence can be used to create site-specifically labeled ADCs [121]. Currently, seven ADCs are approved for therapy. To date, all of these ADCs have been generated by coupling of mAbs to the cytotoxic linker-payload via surface-exposed lysines, or partial disulfide reduction and conjugation to free cysteines, which typically results in a controlled but heterogeneous ADC population with varying numbers and positions of drug molecules attached to the mAb [122]. Homogeneous ADC populations can be achieved by introducing the payload at one or more defined positions. By developing a bioorthogonal tRNA/synthetase pair, Zimmerman et al. have shown that the optimized non-canonical amino acid para-azidomethylL-phenylalanine (pAMF) can be site-specifically incorporated into the tumor-specific, Her2-binding IgG trastuzumab [123]. Subsequently, the cytotoxic linker payload DBCOPEG-monomethyl auristatin (DBCO-PEG-MMAF) was conjugated to $\mathrm{pAMF}$ via strain-promoted azide-alkyne cycloaddition (SPAAC) copper-free click chemistry.

In the context of dual-functioning molecules, bispecific antibodies have also emerged as promising anti-cancer agents. One of the advantages of these proteins is their capability to target two different epitopes simultaneously, thereby increasing target engagement, where mono-specific antibodies might fail [124]. Due to their open design, CFPS reactions can easily be manipulated, for example by varying the template ratios and concentrations of $\mathrm{HC}$ and LC. For example, Xu et al. showed the successful assembly of bispecific 'knobs-into-holes' antibodies in multiple scaffolds by using an E. coli-based CF expression platform [125].

Taken together, antibody evolution, selection, and engineering can dramatically benefit from the technological advances in the field of CFPS. (1) Novel display technologies based on CF methods enable the in vitro evolution of multimeric proteins and allow for more sophisticated protein engineering. (2) Due to the very short time frame from 
synthesis to functional testing, CF systems can accelerate antibody construct evaluation by a repetitive (one after one) and/or parallel screening. (3) The introduction of non-canonical amino acids expands the chemical repertoire and thus the possibilities to modify and improve antibody-based therapeutics. Advanced labeling technologies allow for a very fast qualitative analysis of drug-to-antibody ratio (DAR), linker, linker/position, drug, drug/position (research application), and allow full control of the ADC design (commercial application).

\subsection{Application of Cell-Free Synthesis in Vaccine Development}

CF systems are becoming a potential option for synthesizing vaccine antigens. Most of the vaccine antigens produced by CF systems to date have used E. coli and WGL. Recent progress on eukaryotic CF systems may offer additional advantages. In this context, eukaryotic CF systems are endotoxin free and lack the complex plasma membrane that makes the protein purification simple. Some of the antigens synthesized by using CF systems are highlighted in Table 4. They are able to induce a strong immune response in experimental animals and could serve as a proof of concept for future vaccine development. Using recent advances in CFPS technology, a freeze-dried, cell-free (FD-CF) expression system was created based on $E$. coli $\mathrm{CF}$ lysates [31]. Using this FD-CF technique, diphtheria toxoid antigen variants (DT5 and DT6) were produced following rehydration with water and functional characterization of the synthesized proteins was verified following administration in mice and measuring the immune response [31]. The FD-CF method could enable the production of on-demand, point-of-care biologics requiring just the simple addition of water for activation and synthesis.

Recently, CF-based expression has proven successful in producing difficult-to-express proteins like major outer membrane protein (mMOMP) of Chlamydia spp., a major vaccine antigen. Using E. coli-based CFPS, mMOMP was synthesized in a native trimeric form in the presence of nanolipoproteins (NLPs) with a yield of around $1.5 \mathrm{mg} / \mathrm{mL}$. When injected into mice in the presence of an adjuvant, the protein elicited an enhanced humoral immune response
[126]. This method of synthesizing and simultaneous incorporation of antigens into NLPs using a CF approach is a promising method for future vaccine development.

Conjugate vaccines are one of the safest and most effective biologics [127]. Bioconjugate vaccines are produced using protein glycan coupling technology (PGCT). However, PGCT has its own limitations such as time-consuming in vivo processes. Additionally, FDA-approved carrier proteins, such as toxins derived from Clostridium tetani and Corynebacterium diphtheria, have not yet been demonstrated to be compatible with an E. coli-based production process. Relevant PTMs are often difficult to synthesize in E. coli $\mathrm{CF}$ systems.

Meanwhile, there have been further advances in using bacterial glycoengineering combined with CFPS for producing bioconjugate vaccines. This $\mathrm{CF}$ glycoprotein synthesis (CFGpS) used glycooptimized E. coli extracts integrating both $N$-linked glycosylation and protein synthesis. Using CFGpS, two bioconjugate vaccines were synthesized against F. tularensis and E. coli $\mathrm{O} 78$ [146, 147]. Besides posttranslational modification, the assembly of macromolecular structures in CF systems is highly ambitious. Virus-like particles (VLPs), for example, are nanoscale structures that are formed from the self-assembly of viral proteins without the viral genome responsible for the infection. Usually, VLPs mimic the capsid structure of the real virus. VLP antigens are vaccine candidates for several diseases [148]. One of the vaccine candidates, which is currently in clinical trials, contains VLP antigens addressing noroviruses responsible for gastroenteritis in humans [149]. CF synthesized VLPs were structurally confirmed by electron microscopy [150].

\subsection{Antimicrobial Compounds}

Using E. coli CF systems, antimicrobial colicins (Colicin M, La, E1, and E2) have been synthesized with high yields (around $300 \mu \mathrm{g} / \mathrm{mL}$ ) and solubility. The synthesized colicins are able to effectively kill the target cells without any purification [151]. Antimicrobial peptides (AMPs) are another class of defense molecules that have a wide spectrum of targets; for example, bacteria, viruses, fungi, parasites, and cancer. AMPs are evolving as alternatives to antibiotics [152]. Using lyophilized E. coli CF lysates, ten different AMPs have been synthesized successfully and the functionality of 
Table 4 Vaccine antigens synthesized by using cell-free systems

\begin{tabular}{|c|c|c|c|}
\hline Protein/antigen & Source/disease & Cell-free system & Immune response \\
\hline mMOMP & Chlamydia muridarum & E. coli & $\begin{array}{l}\text { ELISA results showed mMOMP-tNLP with CpG adjuvant, } \\
\text { when injected into mice, produced significant levels of } \\
\text { antigen-specific antibody [126] }\end{array}$ \\
\hline DT5 \& DT6 & Diphtheria & E. coli & $\begin{array}{l}\text { ELISA quantification showed a strong induction of anti-DT } \\
\text { IgG Ab production in DT5-immunized mice [31] }\end{array}$ \\
\hline $\begin{array}{l}\text { Trivalent vaccine based on } \\
\mathrm{HcA}, \mathrm{HcB} \text { and } \mathrm{HcE}\end{array}$ & Botulism & E. coli & $\begin{array}{l}\text { Immunization with trivalent }(\mathrm{HcA}, \mathrm{HcB} \text { and } \mathrm{HcE}) \text { vaccine- } \\
\text { protected mice against the high-dose botulinum } \mathrm{A}, \mathrm{B} \text { and } \mathrm{E} \\
\text { multitoxin challenge }[128]\end{array}$ \\
\hline $\begin{array}{l}\text { Trimeric hemagglutinin (HA) } \\
\text { head and stem domains }\end{array}$ & Influenza & E. coli & $\begin{array}{l}\text { ELISA results confirmed the immunogenic conformation of } \\
\text { HA stem trimer by using antibodies specific for neutralizing } \\
\text { epitopes located in the HA stem domain [48] }\end{array}$ \\
\hline$\alpha \mathrm{CD} 19-\mathrm{Id}$ & B cells of tumors & E. coli & $\begin{array}{l}\alpha \mathrm{CD} 19-\mathrm{Id} \text { induced a robust Id-specific IgG response and } \\
\text { protection to the vaccinated mice [131] }\end{array}$ \\
\hline Lymphoma vaccine & B cells of tumors & E. coli & $\begin{array}{l}\text { Mice injected with } 38 \mathrm{C} 13-\mathrm{scFv} \text { fusion protein-induced anti- } \\
\text { bodies that recognize native } 38 \mathrm{C} 13 \text { protein [132] }\end{array}$ \\
\hline Plasmodium rhoptry proteins & Plasmodium falciparum & $\mathrm{HeLa} /$ wheat germ & Rhoptry-specific animal antisera $[129,130]$ \\
\hline $\begin{array}{l}\text { Malaria antigens (PfMSA180, } \\
\text { LSA3, MSP11, PfRON12, } \\
\text { PfRipr, EXP1, Pfs-GPI, etc) }\end{array}$ & Plasmodium falciparum & Wheat germ & $\begin{array}{l}\text { Interaction of PfMSA180 with CD47 was confirmed by } \\
\text { erythrocyte binding assay [133]. Antigen-specific IgG } \\
\text { responses to LSA3-C were profiled by an alphaScreen assay } \\
\text { [134]. Western blotting and ELISA confirmed the interac- } \\
\text { tion of purified recombinant MSP11 with human sera [135] } \\
\text { Immunization of purified PfRON12 with Freund's complete } \\
\text { adjuvant into Japanese white rabbits generated PfRON12 } \\
\text { antisera [136]. Rabbits immunized with expressed PfRipr } \\
\text { produced specific antibodies [137]. Anti-EXP1 antibod- } \\
\text { ies were generated by immunization of recombinant EXP1 } \\
\text { [138]. Mice immunization with purified Pfs } 25 \text { induced } \\
\text { antiserum [139] }\end{array}$ \\
\hline Pfs25-GPI & Plasmodium falciparum & E. coli & $\begin{array}{l}\text { Immunogenicity was confirmed by ELISA after immuniz- } \\
\text { ing the mice with Pfs } 25-\text { GPI. SMFA was used to verify the } \\
\text { functionality of induced antiPfs25-GPI antibodies [142] }\end{array}$ \\
\hline FhSAP2 & Fasciola hepatica & RRL & $\begin{array}{l}\text { ELISA was used to confirm the antigenicity by reacting with } \\
\text { antibody and animal serum [67] }\end{array}$ \\
\hline Recombinant PV32 & Plasmodium vivax & Wheat germ & $\begin{array}{l}\text { Humoral immune response of serum against the PV } 32 \text { was } \\
\text { confirmed by MFI measurements using PV } 32 \text { protein arrays } \\
{[140]}\end{array}$ \\
\hline PvGAMA & Plasmodium vivax & Wheat germ & $\begin{array}{l}\text { ELISA results presented that humoral immune response from } \\
\text { the patients injected with PvGAMA showed a significant } \\
\text { increase in the anti-PvGAMA antibody response [143] }\end{array}$ \\
\hline HbC-VLP & Hepatitis B virus & E. coli & $\begin{array}{l}\text { Antigenicity of HBc VLPs was confirmed by ELISA against } \\
\text { mAb C1-5 [141] }\end{array}$ \\
\hline HPIV3-HN & $\begin{array}{l}\text { Human parainfluenza } \\
\text { virus } 3\end{array}$ & Wheat germ & $\begin{array}{l}\text { ELISA-based screening of Hybridomas created from the sple- } \\
\text { nocytes of Balb/c mice immunized with purified full-length } \\
\text { HPIV3-HN showed higher absorbance corresponding to } \\
\text { higher specificity [144] }\end{array}$ \\
\hline CLDN-5 & $\begin{array}{l}\text { Tight junctions extracel- } \\
\text { lular regions (ECR) }\end{array}$ & Wheat germ & $\begin{array}{l}\text { Proteoliposomal engineered CLDN-5 antigens induced anti- } \\
\text { CLDN5-5-ECR antibodies in mice [145] }\end{array}$ \\
\hline
\end{tabular}

$\alpha C D 19-I d$ small diabody (Db) molecule containing both a B-cell-targeting moiety (anti-CD19) and a lymphoma Id, 38C13-scFv idiotype-specific single-chain variable fragment of the immunoglobulin from the $38 \mathrm{C} 13$ mouse B-cell lymphoma, $C L D N-5$ claudin-5, CpG 5'-C-phosphateG-3', DT5 and DT6 diphtheria toxoid antigen variants, E. coli Escherichia coli, ELISA enzyme-linked immunosorbent assay, EXP1 Plasmodium falciparum exported protein, FhSAP2 Fasciola hepatica saposin-like protein-2, $H b C$ - $V L P$ hepatitis B core protein virus-like particle, $H c A$, $H c B$, and $H c E$ heavy-chain fragment of botulinum toxins A, B, and C, LSA3 liver stage antigen-3, HPIV3-HN human parainfluenza virus 3 hemagglutinin-neuraminidase, $m M O M P$ major outer membrane protein, $M S P 11$ merozoite surface protein 11, PfMSA180 P. falciparum merozoite surface antigen 180, PfRipr P. falciparum Rh5 interacting protein, PfRON12 P. falciparum rhoptry neck protein, Pfs25-GPI glycosylphosphatidylinositol anchored post-fertilization stage parasite surface antigen $25, P V 32$ P. vivax 32, PvGAMA $P$. vivax glycosylphosphatidylinositol-anchored micronemal antigen, $R R L$ rabbit reticulocyte lysate, $S M F A$ standard membrane feeding assay, $t N L P$ telodendrimer nanolipoprotein particle 
BP100, Cecropin B, and Cecropin P1 was demonstrated by E. coli inhibition assay [31].

\subsection{Site-Directed Labeling of Proteins}

When non-canonical amino acids (ncAAs) are incorporated into proteins, novel functional, structural, and imaging properties can be generated. This synthetic biology application is fast emerging and has wide applications such as incorporating precise PTMs and adding novel functions to proteins [23, 24, 42, 45]. By taking advantage of the openness of the CFPS, one can add the machinery responsible for the co-translational incorporation of ncAAs directly to the standard reaction components. One possible method to incorporate ncAA is to use precharged tRNAs harboring the ncAA. One of the most commonly used methods is the amber suppression technology using an orthogonal pair of aminoacyl-tRNA synthetase/tRNA ( $O$-tRNA/aaRS pairs from distinct organisms), which functions independent of endogenous AARSs and tRNAs in the host and is used to direct the incorporation of ncAAs to specific positions such as the amber stop codon (UAG). After incorporation of an ncAA with a reactive group, bioorthogonal click reactions can be performed to conjugate a molecule of interest.

The most general biorthogonal click reactions for conjugating molecular probes or polymers are the copper-catalyzed azide-alkyne cycloaddition (CuAAC), Staudinger-ligation, photo click cycloaddition, strain-promoted azide-alkyne cycloaddition (SPAAC) and inverse electron-demand DielsAlder cycloadditions (IEDDA + SPIEDAC). Using E. colibased CF systems, Cui et al. showed the incorporation of two fluorescent labels, BODIPY fluorophore and TAMRADIBO, by using a precharged tRNA + orthogonal system for FRET measurements [153]. Using $S f 21$-based CF systems, Quast et al. demonstrated the incorporation of $p$-azido-L-phenylalanine at defined amber positions in parallel in the two subunits of the human EGFR protein dimer. Later, the azido group of the incorporated AzFs was coupled by photoaffinity cross-linking using a bis-COMBO linker to create a stable synthetic dimer of EGFR [14]. The dimerized protein shows autophosphorylation in the presence of tyrosine kinase. In general, release factor 1 (RF1) competes with orthogonal ncAAtRNA for the amber codon, which results in truncated products along with successfully suppressed products. So, CF lysates derived from genetically modified $E$. coli lacking release factor 1 (RF1) can be used to enhance the incorporation efficiency of ncAAs. Using the orthogonal system and E. coli-based CFPS, human MEK1 kinase with PTMs was synthesized up to milligram quantities by site-specific, co-translational incorporation of phosphoserine at specific positions [154].

Various polyethylene glycol (PEG) moieties have been widely used to decorate therapeutic proteins. The PEG moiety usually offers high stability and extends the half-life of proteins while in circulation inside the body. The Food and Drug Administration (FDA) has recognized PEG moieties as safe due to their structural flexibility, hydrophilicity, and minimal toxicity, and several PEGylated drugs have been approved by the FDA. Using Sf21-based CF systems, a site-specific PEGylated human EPO was produced and characterized by autoradiography [45]. Apart from the amber suppression strategy, there are other strategies like frameshift suppression, sense codon reassignment, and unnatural base pairing. A detailed review of prominent methods for the incorporation of ncAAs into proteins using CFPS has been recently published [23].

\section{Commercial Cell-Free Systems}

A wide range of commercial CF systems is available in the market based on lysates derived from diverse sources. As well, a few companies provide services for $\mathrm{CF}$ synthesis of proteins. Some of the products derived from the $\mathrm{CF}$ systems based on E. coli lysates are already in clinical trials, such as ADCs targeting CD74 and folate receptor alpha highly expressed in myeloma and cancer cells (Sutro Biopharma, Inc, USA). Table 5 lists commercial systems currently available for the $\mathrm{CF}$ production of proteins.

\section{Outlook and Future Directions}

Evolving CF systems from a laboratory level to a robust production platform is necessary to fulfill their potential. Prior to full realization of CF systems as emerging tools for drug discovery and evaluation, several factors need to be addressed, like synthesis of the high-quality functional protein with proper folding and PTM, cost of production, scalability, and safety issues. A more detailed understanding of the components in the CF lysates will substantially improve the quality and stability of the extract preparation. The quantity of the protein depends on the translation efficiency of the CF system. The most important factors that influence the protein yields are quality of the celllysate, reaction conditions, and template optimization as addressed in section 3.2. To increase the translation efficiency, further efforts are required to increase the quality of lysate production. This can be achieved by using genetic engineering tools to remove the factors responsible for nucleic acid degradation, ribosome inactivation, and protein degradation. Brodiazhenko et al. showed that genomic disruption of genes encoding ribosome-inactivating factors (HPF in B. subtilis and Stm1 in S. cerevisiae) has improved the activities of bacterial and yeast translation systems [54]. In this context, advanced engineering tools like CRISPR Cas could help to improve the translation 
Table 5 List of commercially available cell-free synthesis kits in the market

\begin{tabular}{|c|c|c|}
\hline Commercial kit & Cell-free lysate & Company \\
\hline PURExpress In Vitro Protein Synthesis Kit & PURE/E. coli & New England Biolabs, USA \\
\hline TnT Quick Coupled Transcription/Translation System & RRL & Promega, USA \\
\hline Flexi Rabbit Reticulocyte Lysate System & RRL & Promega, USA \\
\hline TnT Coupled Wheat Germ Extract System & Wheat germ & Promega, USA \\
\hline TnT SP6 High-Yield Wheat Germ Protein Expression System & Wheat germ & Promega, USA \\
\hline TnT T7 Insect Cell Extract Protein Expression System & Sf21 system & Promega, USA \\
\hline E. coli $\mathrm{S} 30$ Extract System & E. coli & Promega, USA \\
\hline $\mathrm{XpressCF}+{ }^{\mathrm{TM}}$ & E. coli & Sutro Biopharma, USA \\
\hline myTXTL & E. coli & Arbor Biosciences, USA \\
\hline Retic Lysate IVT Kit & RRL & Thermo Fisher Scientific, USA \\
\hline MembraneMax & E. coli & Thermo Fisher Scientific, USA \\
\hline Expressway Mini/Maxi & E. coli & Thermo Fisher Scientific, USA \\
\hline 1-Step CHO High-Yield IVT Kit & $\mathrm{CHO}$ & Thermo Fisher Scientific, USA \\
\hline 1-Step Human coupled/High-yield IVT Kit & HeLa & Thermo Fisher Scientific, USA \\
\hline In Vitro (cell-free) LEXSY & Leishmania tarentolae & Jena Bioscience, Germany \\
\hline AccuRapid & E. coli & BIONEER, South Korea \\
\hline RTS $100 / 500$ wheat germ & Wheat Germ & biotechrabbit, Germany \\
\hline RTS 100/500/9000 E. coli HY & E. coli & biotechrabbit, Germany \\
\hline RTS 100 & Sf21 & biotechrabbit, Germany \\
\hline PUREfrexTM & PURE/ E. coli & Eurogentec, Belgium \\
\hline Next Generation Cell Free Protein Expression Kit & Wheat germ & Sigma-Aldrich, USA \\
\hline iPE-Quick Kit & E. coli & Sigma-Aldrich, USA \\
\hline WEPRO TT Premium ONE/PLUS Expression Kit & Wheat germ & CellFree Sciences Co., Ltd, Japan \\
\hline ALiCE Cell-Free Protein Expression & Tobacco BY-2 & Leniobio, Germany \\
\hline Human Cell-Free Protein Expression Maxi System & Cultured human cells & Takara Bio, Japan \\
\hline
\end{tabular}

CHO Chinese hamster ovary, E. coli Escherichia coli, IVT in vitro translation, PURE Protein synthesis Using Recombinant Elements, RRL rabbit reticulocyte lysate, RTS rapid translation systems, Sf21 Spodoptera frugiperda 21

efficiency of the CF systems [155]. Activation and enrichment of translation-relevant factors could also increase translation efficiency [63].

When it comes to eukaryotic CFPS platforms, translocation through microsomes currently remains a black box. Optimizing the efficiency of coupling translation and translocation needs to be addressed. The most important issue with CF systems, especially when working with CECF systems, is to maintain the balance between the amount of protein synthesized and the stability and quality of the protein. Although CECF has been capable of producing $0.6-1 \mathrm{mg}$ protein per $\mathrm{mL}$, especially with the mammalian expression systems, only a small fraction of the produced protein was subject to detailed functional analysis $[15,155]$. This is one of the reasons why the functional assays are limited to binding assays (GPCR, TLR, antibody), PLBE (ion channels), and colorimetric assays (enzymes). By optimizing the redox conditions, the problem of $\mathrm{Ab}$ translocation into the lumen of microsomes is addressed already [75, 155]. However, when it comes to the synthesis of complex transmembrane proteins in mammalian systems, the insertion efficiency might be already saturated at the low synthesis rates due to restrictions on the level of the translocon's functionality. A more detailed analysis of lipid composition and proteins constituting the microsomes present in the insect, $\mathrm{CHO}$, and human-derived lysates will help to improve the quality of synthesized membrane proteins. One could use alternative supplements like nanodiscs or liposomes reconstituted from microsomal membranes to support MP integration [156]. Intense efforts on designing novel and improved mammalian CF systems should be maintained as the majority of the drug targets are related to complex eukaryotic proteins. Optimizing CF reactions in order to decrease protein aggregation during the purification processes and increasing the quality of the protein purification, especially when using the CECF method, is strongly required.

Another point to address in the field of CFPS is to decrease the costs of production, especially in the preparation of CF lysates and the individual reaction components. Substantial costs arise from the usage of phosphorylated energy systems, cofactors, nucleotides, amino acids, and 
DNA. Alternative energy regeneration systems are available in the place of phosphorylated substrates (e.g., glucose, maltodextrin, etc.) for sustainable ATP regeneration throughout the synthesis reaction [157-159]. Use of nucleoside monophosphates instead of nucleoside triphosphates as the nucleotide source in the CF systems could be another cost-effective parameter [159]. Avoiding the use of exogenous tRNAs and cyclic AMPs and reducing the concentration of amino acids and nucleotides are some of the cost-effective parameters one could optimize during protein synthesis. Additionally, new high-cell-density cultivation strategies and improvement in the quality of cell lines by genetic engineering could help to produce cost-effective high-quality CF systems. Costs can also be decreased by engineering and optimization of eukaryotic lysates to extend the lifetime of these systems, thereby increasing the yield of the produced protein.

There has been considerable progress in the point-ofcare production devices for on-demand biologic synthesis of small quantities of therapeutic proteins using $\mathrm{CHO}$ lysates and E. coli lysates through on-site good manufacturing practice (GMP) [30]. This type of miniaturized device could be useful for quick testing of proteins and thus help in treating common and rare diseases, and CFPS could help solve the challenges associated with in vivo expression.

Due to the open nature of the CF systems, proteins can be modified with chemically synthesized glycans by bioconjugate chemistries. This will help to increase the quality and therapeutic efficiency of the synthesized proteins. There is an exponential increase in the number of publications from the last 5 years using CF lysates for producing a wide range of proteins [160]. Due to the increased awareness of the biosynthetic potential of the CF systems, protocols becoming simpler, improvement in the lysate quality, and its applicability in the preparation of a diverse range of proteins, there will be unexpected outcomes in the field of protein production towards future drug development.

\section{Compliance with Ethical Standards}

Funding This research is supported by the European Regional Development Fund (EFRE) and the German Ministry of Education and Research (BMBF, No. 031B0078A).

Conflict of interest Srujan Kumar Dondapati, Marlitt Stech, Anne Zemella, and Stefan Kubick have no conflicts of interest that might be relevant to the contents of this article.

Open Access This article is licensed under a Creative Commons Attribution-NonCommercial 4.0 International License, which permits any non-commercial use, sharing, adaptation, distribution and reproduction in any medium or format, as long as you give appropriate credit to the original author(s) and the source, provide a link to the Creative Commons licence, and indicate if changes were made. The images or other third party material in this article are included in the article's Creative Commons licence, unless indicated otherwise in a credit line to the material. If material is not included in the article's Creative Commons licence and your intended use is not permitted by statutory regulation or exceeds the permitted use, you will need to obtain permission directly from the copyright holder.To view a copy of this licence, visit http://creativecommons.org/licenses/by-nc/4.0/.

\section{References}

1. Imbrici P, Nicolotti O, Leonetti F, Conte D, Liantonio A. Ion channels in drug discovery and safety pharmacology. Methods Mol Biol. 2018;1800:313-26.

2. Lin L, Yee SW, Kim RB, Giacomini KM. SLC transporters as therapeutic targets: emerging opportunities. Nat Rev Drug Discov. 2015;14:543-60.

3. Oprea TI, Bologa CG, Brunak S, Campbell A, Gan GN, Gaulton A, et al. Unexplored therapeutic opportunities in the human genome. Nat Rev Drug Discov. 2018;17:317-32.

4. Bull SC, Doig AJ. Properties of protein drug target classes. PLoS One. 2015;10:2015.

5. Wulff H, Christophersen P, Colussi P, Chandy KG, Yarov-Yarovoy V. Antibodies and venom peptides: new modalities for ion channels. Nat Rev Drug Discov. 2019;18:339-57.

6. Kung JE, Jura N. Prospects for pharmacological targeting of pseudokinases. Nat Rev Drug Discov. 2019;18:501-26.

7. Molchanova N, Hansen PR, Franzyk H. Advances in development of antimicrobial peptidomimetics as potential drugs. Molecules. 2017;20:22.

8. Rosano GL, Morales ES, Ceccarelli EA. New tools for recombinant protein production in Escherichia coli: a 5-year update. Protein Sci. 2019;28:1412-22.

9. Sachse R, Dondapati SK, Fenz SF, Schmidt T, Kubick S. Membrane protein synthesis in cell-free systems: From bio-mimetic systems to bio-membranes. FEBS Lett. 2014;588:2774-81. https ://doi.org/10.1016/j.febslet.2014.06.007.

10. Jin X, Hong SH. Cell-free protein synthesis for producing difficult-to-express proteins. Biochem Eng J. 2018;138:156-64. https ://doi.org/10.1016/j.bej.2018.07.013.

11. Gregorio NE, Levine MZ, Oza JP. A user's guide to cell-free protein synthesis. Methods Protoc. 2019;2:24. https://doi. org/10.3390/mps2010024.

12. Des Soye BJ, Davidson SR, Weinstock MT, Gibson DG, Jewett MC. Establishing a high-yielding cell-free protein synthesis platform derived from vibrio natriegens. ACS Synth Biol. 2018;7:2245-55.

13. Zemella A, Thoring L, Hoffmeister C, Kubick S. Cell-free protein synthesis: pros and cons of prokaryotic and eukaryotic systems. Chembiochem Eur J Chem Biol. 2015;16:2420-31. https://doi.org/10.1002/cbic.201500340.

14. Quast RB, Sonnabend A, Stech M, Wüstenhagen DA, Kubick S. High-yield cell-free synthesis of human EGFR by IRESmediated protein translation in a continuous exchange cellfree reaction format. Sci Rep. 2016;6:30399. https://doi. org/10.1038/srep30399.

15. Merk H, Gless C, Maertens B, Gerrits M, Stiege W. Cellfree synthesis of functional and endotoxin-free antibody Fab fragments by translocation into microsomes. Biotechniques. 2012;53:153-60.

16. Orth JH, Schorch B, Boundy S, Ffrench-Constant R, Kubick S, Aktories K. Cell-free synthesis and characterization of a novel cytotoxic pierisin-like protein from the cabbage butterfly Pieris rapae. Toxicon. 2011;57:199-207. 
17. Gurramkonda C, Rao A, Borhani S, Pilli M, Deldari S, Ge X, et al. Improving the recombinant human erythropoietin glycosylation using microsome supplementation in $\mathrm{CHO}$ cell-free system. Biotechnol Bioeng. 2018;115:1253-64.

18. Dondapati SK, Pietruschka G, Thoring L, Wüstenhagen DA, Kubick S. Cell-free synthesis of human toll-like receptor 9 (TLR9): optimization of synthesis conditions and functional analysis. PLoS One. 2019;14:e0215897. https://doi. org/10.1371/journal.pone.0215897.

19. Thoring L, Wustenhagen DA, Borowiak M, Stech M, Sonnabend A, Kubick S. Cell-free systems based on CHO cell lysates: optimization strategies, synthesis of "difficultto-express" proteins and future perspectives. PLoS One. 2016;11:2016.

20. Rues RB, Dong F, Dotsch V, Bernhard F. Systematic optimization of cell-free synthesized human endothelin B receptor folding. Methods. 2018;147:73-83.

21. Carlson ED, Gan R, Hodgman CE, Jewett MC. Cell-free protein synthesis: applications come of age. Biotechnol Adv. 2012;30:1185-94.

22. Lu Y. Cell-free synthetic biology: engineering in an open world. Synth Syst Biotechnol. 2017;2:23-7. https://doi.org/10.1016/j. synbio.2017.02.003.

23. Quast RB, Mrusek D, Hoffmeister C, Sonnabend A, Kubick S. Cotranslational incorporation of non-standard amino acids using cell-free protein synthesis. FEBS Lett. 2015;589:1703-12.

24. Martin RW, Des Soye BJ, Kwon Y-C, Kay J, Davis RG, Thomas PM, et al. Cell-free protein synthesis from genomically recoded bacteria enables multisite incorporation of noncanonical amino acids. Nat Commun. 2018;9:1203. https://doi.org/10.1038/s4146 7-018-03469-5.

25. Zawada JF, Yin G, Steiner AR, Yang J, Naresh A, Roy SM, et al. Microscale to manufacturing scale-up of cell-free cytokine production-a new approach for shortening protein production development timelines. Biotechnol Bioeng. 2011;108:1570-8.

26. Georgi V, Georgi L, Blechert M, Bergmeister M, Zwanzig M, Wüstenhagen DA, et al. On-chip automation of cell-free protein synthesis: new opportunities due to a novel reaction mode. Lab Chip. 2016;16:269-81. https://doi.org/10.1039/c5lc00700c.

27. Zhang H, Lee MY, Hogg MG, Dordick JS, Sharfstein ST. Highthroughput transfection of interfering RNA into a 3D cell-culture chip. Small. 2012;8:2091-8.

28. Datta P, Meli L, Li L, Migliore N, Schaefer E, Sharfstein ST, et al. Microarray platform affords improved product analysis in mammalian cell growth studies. Biotechnol J. 2014;9:386-95.

29. Quast RB, Kortt O, Henkel J, Dondapati SK, Wüstenhagen DA, Stech M, Kubick S. Automated production of functional membrane proteins using eukaryotic cell-free translation systems. J Biotechnol. 2015;203:45-53.

30. Adiga R, Al-Adhami M, Andar A, Borhani S, Brown S, Burgenson D, et al. Point-of-care production of therapeutic proteins of good-manufacturing-practice quality. Nat Biomed Eng. 2018;2:675-86.

31. Pardee K, Slomovic S, Nguyen PQ, Lee JW, Donghia N, Burrill $\mathrm{D}$, et al. Portable, on-demand biomolecular manufacturing. Cell. 2016;167:248-59.

32. Kelwick R, Webb AJ, MacDonald JT, Freemont PS. Development of a Bacillus subtilis cell-free transcription-translation system for prototyping regulatory elements. Metab Eng. 2016;38:370-81.

33. Wang H, Li J, Jewett MC. Development of a Pseudomonas putida cell-free protein synthesis platform for rapid screening of gene regulatory elements. Synth Biol. 2018. https://doi.org/10.1093/ synbio/ysy003.

34. Li J, Wang H, Kwon YC, Jewett MC. Establishing a high yielding streptomyces-based cell-free protein synthesis system. Biotechnol Bioeng. 2017;114:1343-53.
35. Buntru M, Vogel S, Spiegel H, Schillberg S. Tobacco BY-2 cellfree lysate: an alternative and highly-productive plant-based in vitro translation system. BMC Biotechnol. 2014;14:37. https ://doi.org/10.1186/1472-6750-14-37.

36. Kovtun O, Mureev S, Jung W, Kubala MH, Johnston W, Alexandrov K. Leishmania cell-free protein expression system. Methods. 2011;55:58-64.

37. Wu C, Dasgupta A, Shen L, Bell-Pedersen D, Sachs MS. The cell free protein synthesis system from the model filamentous fungus Neurospora crassa. Methods. 2018;137:11-9.

38. Gan R, Jewett MC. A combined cell-free transcription-translation system from Saccharomyces cerevisiae for rapid and robust protein synthe. Biotechnol J. 2014;9:641-51.

39. Burgenson D, Gurramkonda C, Pilli M, Ge X, Andar A, Kostov Y, et al. Rapid recombinant protein expression in cell-free extracts from human blood. Sci Rep. 2018;8:18-27846.

40. Kuruma Y, Ueda T. The PURE system for the cell-free synthesis of membrane proteins. Nat Protoc. 2015;10:1328-44.

41. Jaroentomeechai T, Stark JC, Natarajan A, Glasscock CJ, Yates LE, Hsu KJ, et al. Single-pot glycoprotein biosynthesis using a cell-free transcription-translation system enriched with glycosylation machinery. Nat Commun. 2018;9:2686. https://doi. org/10.1038/s41467-018-05110-x.

42. Venkat S, Chen H, Gan Q, Fan C. The application of cell-free protein synthesis in genetic code expansion for post-translational modifications. Front Pharmacol. 2019;10:248. https://doi. org/10.3389/fphar.2019.00248.

43. Harbers M. Wheat germ systems for cell-free protein expression. FEBS Lett. 2014;588:2762-73.

44. Lyford LK, Rosenberg RL. Cell-free expression and functional reconstitution of homo-oligomeric alpha7 nicotinic acetylcholine receptors into planar lipid bilayers. J Biol Chem. 1999;274:25675-81.

45. Zemella A, Thoring L, Hoffmeister C, Samalikova M, Ehren $\mathrm{P}$, Wustenhagen DA, Kubick S. Cell-free protein synthesis as a novel tool for directed glycoengineering of active erythropoietin. Sci Rep. 2018;8:18-26936.

46. Thoring L, Dondapati SK, Stech M, Wustenhagen DA, Kubick S. High-yield production of "difficult-to-express" proteins in a continuous exchange cell-free system based on $\mathrm{CHO}$ cell lysates. Sci Rep. 2017;7:17-12188.

47. Gagoski D, Polinkovsky ME, Mureev S, Kunert A, Johnston W, Gambin Y, Alexandrov K. Performance benchmarking of four cell-free protein expression systems. Biotechnol Bioeng. 2016;113:292-300.

48. Lu Y, Welsh JP, Swartz JR. Production and stabilization of the trimeric influenza hemagglutinin stem domain for potentially broadly protective influenza vaccines. Proc Natl Acad Sci USA. 2014;111:125-30. https://doi.org/10.1073/pnas.1308701110.

49. Kovácsová G, Gustavsson E, Wang J, Kreir M, Peuker S, Westenhoff S. Cell-free expression of a functional pore-only sodium channel. Prot Express Purif. 2015;111:42-7. https://doi. org/10.1016/j.pep.2015.03.002.

50. Holm-Bertelsen J, Bock S, Helmstetter F, Beitz E. High-level cell-free production of the malarial lactate transporter PfFNT as a basis for crystallization trials and directional transport studies. Protein Expr Purif. 2016;126:109-14.

51. Dondapati SK, Wstenhagen DA, Strauch E, Kubick S. Cell-free production of pore forming toxins: functional analysis of thermostable direct hemolysin from Vibrio parahaemolyticus. Eng Life Sci. 2018;18:140-8. https://doi.org/10.1002/elsc.201600259.

52. Cortes S, Barette C, Beroud R, de Waard M, Schaack B. Functional characterization of cell-free expressed Kv1.3 channel using a voltage-sensitive fluorescent dye. Prot Exp Purif. 2018;145:94-9. 
53. Deniaud A, Liguori L, Blesneac I, Lenormand JL, PebayPeyroula E. Crystallization of the membrane protein hVDAC1 produced in cell-free system. Biochim Biophys Acta. 2010;2010:1540-6.

54. Brodiazhenko T, Johansson MJO, Takada H, Nissan T, Hauryliuk V, Murina V. Elimination of ribosome inactivating factors improves the efficiency of Bacillus subtilis and Saccharomyces cerevisiae cell-free translation systems. Front Microbiol. 2018;9:2018.

55. Failmezger J, Scholz S, Blombach B, Siemann-Herzberg M. Cell-free protein synthesis from fast-growing vibrio natriegens. Front Microbiol. 2018;9:1146. https://doi.org/10.3389/fmicb .2018.01146.

56. Dondapati SK, Kreir M, Quast RB, Wustenhagen DA, Bruggemann A, Fertig N, Kubick S. Membrane assembly of the functional KcsA potassium channel in a vesicle-based eukaryotic cellfree translation system. Biosens Bioelectron. 2014;59:174-83.

57. Quast RB, Ballion B, Stech M, Sonnabend A, Varga BR, Wustenhagen DA, et al. Cell-free synthesis of functional human epidermal growth factor receptor: Investigation of ligand-independent dimerization in Sf21 microsomal membranes using non-canonical amino acids. Sci Rep. 2016;20:6.

58. Thoring L, Zemella A, Wustenhagen D, Kubick S. Accelerating the production of druggable targets: eukaryotic cell-free systems come into focus. Methods Protoc. 2019;20:2.

59. Tran K, Gurramkonda C, Cooper MA, Pilli M, Taris JE, Selock $\mathrm{N}$, et al. Cell-free production of a therapeutic protein: expression, purification, and characterization of recombinant streptokinase using a CHO lysate. Biotechnol Bioeng. 2018;115:92-102.

60. Suzuki Y, Ogasawara T, Tanaka Y, Takeda H, Sawasaki T, Mogi $\mathrm{M}$, et al. Functional G-protein-coupled receptor (GPCR) synthesis: the pharmacological analysis of human histamine $\mathrm{H} 1$ receptor (HRH1) synthesized by a wheat germ cell-free protein synthesis system combined with asolectin glycerosomes. Front Pharmacol. 2018;9:2018.

61. Richardson D, Itkonen J, Nievas J, Urtti A, Casteleijn MG. Accelerated pharmaceutical protein development with integrated cell free expression, purification, and bioconjugation. Sci Rep. 2018;8:18-30435.

62. Brodel AK, Sonnabend A, Roberts LO, Stech M, Wustenhagen DA, Kubick S. IRES-mediated translation of membrane proteins and glycoproteins in eukaryotic cell-free systems. PLoS One. 2013;8:2013.

63. Mikami S, Masutani M, Sonenberg N, Yokoyama S, Imataka $\mathrm{H}$. An efficient mammalian cell-free translation system supplemented with translation factors. Protein Expr Purif. 2006;46:348-57.

64. Anastasina M, Terenin I, Butcher SJ, Kainov DE. A technique to increase protein yield in a rabbit reticulocyte lysate translation system. Biotechniques. 2014;56:36-9. https://doi. org/10.2144/000114125.

65. Liu K, Hu J. Host-regulated hepatitis B virus capsid assembly in a mammalian cell-free system. Bio Protoc. 2018;8:2813.

66. Mureev S, Kovtun O, Nguyen UT, Alexandrov K. Species-independent translational leaders facilitate cell-free expression. Nat Biotechnol. 2009;27:747-52.

67. Ramos-Benitez MJ, Lopez-Cruz LM, Aguayo V, Ruiz-Jimenez C, Espino AM. Cell-free expression, purification and immunoreactivity assessment of recombinant Fasciola hepatica saposin-like protein-2. Mol Biol Rep. 2018;45:1551-6.

68. Ruehrer S, Michel H. Exploiting Leishmania tarentolae cell-free extracts for the synthesis of human solute carriers. Mol Membr Biol. 2013;30:288-302.

69. Wang X, Liu J, Zheng Y, Li J, Wang H, Zhou Y, et al. An optimized yeast cell-free system: sufficient for translation of human papillomavirus $58 \mathrm{~L} 1 \mathrm{mRNA}$ and assembly of virus-like particles. J Biosci Bioeng. 2008;106:8-15.

70. Sullivan CJ, Pendleton ED, Sasmor HH, Hicks WL, Farnum $\mathrm{JB}$, Muto M, et al. A cell-free expression and purification process for rapid production of protein biologics. Biotechnol J. 2016;11:238-48.

71. Sachse R, Wstenhagen D, Šamalíková M, Gerrits M, Bier FF, Kubick S. Synthesis of membrane proteins in eukaryotic cell-free systems. Eng Life Sci. 2013;13:39-48. https://doi.org/10.1002/ elsc.201100235.

72. Yu C-H, Dang Y, Zhou Z, Wu C, Zhao F, Sachs MS, Liu Y. Codon usage influences the local rate of translation elongation to regulate co-translational protein folding. Mol CELL. 2015;59:744-54. https://doi.org/10.1016/j.molcel.2015.07.018.

73. Zhou M, Wang T, Fu J, Xiao G, Liu Y. Nonoptimal codon usage influences protein structure in intrinsically disordered regions. Mol Microbiol. 2016;97:974-87. https://doi.org/10.1111/ mmi.13079.

74. Stech M, Hust M, Schulze C, Dübel S, Kubick S. Cell-free eukaryotic systems for the production, engineering, and modification of scFv antibody fragments. Eng Life Sci. 2014;14:387-98. https ://doi.org/10.1002/elsc.201400036.

75. Stech M, Nikolaeva O, Thoring L, Stocklein WFM, Wustenhagen DA, Hust M, et al. Cell-free synthesis of functional antibodies using a coupled in vitro transcription-translation system based on CHO cell lysates. Sci Rep. 2017;7:17-12364.

76. Kim D, Kang TJ, Kim H, Lee KB. Method for cell-free protein synthesis involved with $\mathrm{pH}$ control with amino acid decarboxylase.

77. Jin X, Kightlinger W, Hong SH. Optimizing cell-free protein synthesis for increased yield and activity of colicins. Methods Protoc. 2019;2:28. https://doi.org/10.3390/mps2020028.

78. Li K, Jiang Q, Bai X, Yang YF, Ruan MY, Cai SQ. Tetrameric assembly of $\mathrm{K}(+)$ channels requires ER-located chaperone proteins. Mol Cell. 2017;65:52-65.

79. Calhoun KA, Swartz JR. Energy systems for ATP regeneration in cell-free protein synthesis reactions. Methods Mol Biol. 2007;375:3-17.

80. Lee KH, Kim DM. Recent advances in development of cell-free protein synthesis systems for fast and efficient production of recombinant proteins. FEMS Microbiol Lett. 2018;20:365.

81. Moon B-J, Lee K-H, Kim D-M. Effects of ATP regeneration systems on the yields and solubilities of cell-free synthesized proteins. J Ind Eng Chem. 2019;70:276-80. https://doi. org/10.1016/j.jiec.2018.10.027.

82. Focke PJ, Hein C, Hoffmann B, Matulef K, Bernhard F, Dötsch $\mathrm{V}$, Valiyaveetil FI. Combining in vitro folding with cell free protein synthesis for membrane protein expression. Biochemistry. 2016;55:4212-9. https://doi.org/10.1021/acs.biochem.6b00488.

83. Henrich E, Hein C, Dotsch V, Bernhard F. Membrane protein production in Escherichia coli cell-free lysates. FEBS Lett. 2015;589:1713-22.

84. Winterstein L-M, Kukovetz K, Rauh O, Turman DL, Braun C, Moroni A, et al. Reconstitution and functional characterization of ion channels from nanodiscs in lipid bilayers. J Gener Physiol. 2018;150:637-46. https://doi.org/10.1085/jgp.20171 1904.

85. Tiefenauer L, Demarche S. Challenges in the development of functional assays of membrane proteins. Materials (Basel). 2012;5:2205-42. https://doi.org/10.3390/ma5112205.

86. Santos R, Ursu O, Gaulton A, Bento AP, Donadi RS, Bologa $\mathrm{CG}$, et al. A comprehensive map of molecular drug targets. Nat Rev Drug Discov. 2017;16:19-34. https://doi.org/10.1038/ nrd.2016.230.

87. Ezure T, Nanatani K, Sato Y, Suzuki S, Aizawa K, Souma S, et al. A cell-free translocation system using extracts of cultured 
insect cells to yield functional membrane proteins. PLoS One. 2014;9:2014.

88. Findlay HE, Harris NJ, Booth PJ. In vitro synthesis of a major facilitator transporter for specific active transport across droplet interface bilayers. Sci Rep. 2016;6:39349.

89. Renauld S, Cortes S, Bersch B, Henry X, de Waard M, Schaack B. Functional reconstitution of cell-free synthesized purified Kv channels. Biochim Biophys Acta Biomembr. 2017;2017:2373-80.

90. Syeda R, Santos JS, Montal M. The sensorless pore module of voltage-gated $\mathrm{K}+$ channel family 7 embodies the target site for the anticonvulsant retigabine. J Biol Chem. 2016;291:2931-7.

91. Keller T, Schwarz D, Bernhard F, Dötsch V, Hunte C, Gorboulev V, Koepsell H. Cell free expression and functional reconstitution of eukaryotic drug transporters. Biochemistry. 2008;47:4552-64. https://doi.org/10.1021/bi800060w.

92. Berrier C, Guilvout I, Bayan N, Park K-H, Mesneau A, Chami $\mathrm{M}$, et al. Coupled cell-free synthesis and lipid vesicle insertion of a functional oligomeric channel MscL MscL does not need the insertase YidC for insertion in vitro. Biochim Biophys Acta. 2010;1808:41-6. https://doi.org/10.1016/j.bbamem.2010.09.018.

93. Zhang X, Lian J, Kai L, Huang L, Cen P, Xu Z. Enhanced functional expression of aquaporin $\mathrm{Z}$ via fusion of in situ cleavable leader peptides in Escherichia coli cell-free system. Enzyme Microb Technol. 2014;55:26-30.

94. Carnarius C, Kreir M, Krick M, Methfessel C, Moehrle V, Valerius $\mathrm{O}$, et al. Green fluorescent protein changes the conductance of connexin $43(\mathrm{Cx} 43)$ hemichannels reconstituted in planar lipid bilayers. J Biol Chem. 2012;287:2877-86.

95. Eckert D, Schulze T, Stahl J, Rauh O, van Etten JL, Hertel B, et al. A small viral potassium ion channel with an inherent inward rectification. Channels. 2019;13:124-35.

96. Nozawa A, Tozawa Y. Incorporation of adenine nucleotide transporter, Ant1p, into proteoliposomes facilitates ATP translocation and activation of encapsulated luciferase. J Biosci Bioeng. 2014;118:130-3.

97. Quast RB, Claussnitzer I, Merk H, Kubick S, Gerrits M. Synthesis and site-directed fluorescence labeling of azido proteins using eukaryotic cell-free orthogonal translation systems. Anal Biochem. 2014;451:4-9. https://doi.org/10.1016/j.ab.2014.01.013.

98. Junge F, Luh LM, Proverbio D, Schafer B, Abele R, Beyermann $\mathrm{M}$, et al. Modulation of G-protein coupled receptor sample quality by modified cell-free expression protocols: a case study of the human endothelin A receptor. J Struct Biol. 2010;172:94-106.

99. Sonnabend A, Spahn V, Stech M, Zemella A, Stein C, Kubick S. Production of G protein-coupled receptors in an insect-based cell-free system. Biotechnol Bioeng. 2017;114:2328-38.

100. Yang J-P, Cirico T, Katzen F, Peterson TC, Kudlicki W. Cellfree synthesis of a functional $\mathrm{G}$ protein-coupled receptor complexed with nanometer scale bilayer discs. BMC Biotechnol. 2011;11:57. https://doi.org/10.1186/1472-6750-11-57.

101. Zemella A, Grossmann S, Sachse R, Sonnabend A, Schaefer M, Kubick S. Qualifying a eukaryotic cell-free system for fluorescence based GPCR analyses. Sci Rep. 2017;7:3740. https://doi. org/10.1038/s41598-017-03955-8.

102. Milligan G. Principles: extending the utility of [35S]GTP gamma S binding assays. Trends Pharmacol Sci. 2003;24:87-90.

103. Stumpf AD, Hoffmann C. Optical probes based on G proteincoupled receptors - added work or added value? Br J Pharmacol. 2016;173:255-66.

104. Luttrell LM, Lefkowitz RJ. The role of beta-arrestins in the termination and transduction of G-protein-coupled receptor signals. J Cell Sci. 2002;115:455-65.

105. Hoffmann C, Gaietta G, Bunemann M, Adams SR, OberdorffMaass S, Behr B, et al. A FlAsH-based FRET approach to determine $\mathrm{G}$ protein-coupled receptor activation in living cells. Nat Methods. 2005;2:171-6.

106. Kauk M, Hoffmann C. Intramolecular and intermolecular FRET sensors for GPCRs - monitoring conformational changes and beyond. Trends Pharmacol Sci. 2018;39:123-35.

107. Zemella A, Richter T, Thoring L, Kubick S. A combined cell-free protein synthesis and fluorescence-based approach to investigate GPCR binding properties. Methods Mol Biol. 2019;2019:57-77.

108. Hanes J, Pluckthun A. In vitro selection and evolution of functional proteins by using ribosome display. Proc Natl Acad Sci USA. 1997;94:4937-42.

109. He M, Taussig MJ. Antibody-ribosome-mRNA (ARM) complexes as efficient selection particles for in vitro display and evolution of antibody combining sites. Nucleic Acids Res. 1997;25:5132-4. https://doi.org/10.1093/nar/25.24.5132.

110. Odegrip R, Coomber D, Eldridge B, Hederer R, Kuhlman PA, Ullman C, et al. CIS display: in vitro selection of peptides from libraries of proteinâ€"DNA complexes. Proc Natl Acad Sci USA. 2004;101:2806-10. https://doi.org/10.1073/pnas.0400219101.

111. Kaplon H, Reichert JM. Antibodies to watch in 2019. MAbs. 2019;11:219-38.

112. Sumida T, Yanagawa H, Doi N. In vitro selection of fab fragments by mRNA display and gene-linking emulsion PCR. J Nucl Acids. 2012;2012:9. https://doi.org/10.1155/2012/371379.

113. Stafford RL, Matsumoto ML, Yin G, Cai Q, Fung JJ, Stephenson $\mathrm{H}$, et al. In vitro Fab display: a cell-free system for IgG discovery. Protein Eng Des Sel. 2014;27:97-109.

114. Groff D, Armstrong S, Rivers PJ, Zhang J, Yang J, Green E, et al. Engineering toward a bacterial "endoplasmic reticulum" for the rapid expression of immunoglobulin proteins. MAbs. 2014;6:671-8.

115. Yin G, Garces ED, Yang J, Zhang J, Tran C, Steiner AR, et al. Aglycosylated antibodies and antibody fragments produced in a scalable in vitro transcription-translation system. MAbs. 2012;4:217-25.

116. Stech M, Merk H, Schenk JA, Stocklein WF, Wustenhagen DA, Micheel B, et al. Production of functional antibody fragments in a vesicle-based eukaryotic cell-free translation system. J Biotechnol. 2012;164:220-31.

117. Kawasaki T, Gouda MD, Sawasaki T, Takai K, Endo Y. Efficient synthesis of a disulfide-containing protein through a batch cellfree system from wheat germ. Eur J Biochem. 2003;270:4780-6.

118. Martin RW, Majewska NI, Chen CX, Albanetti TE, Jimenez RBC, Schmelzer AE, et al. Development of a CHO-based cellfree platform for synthesis of active monoclonal antibodies. ACS Synth Biol. 2017;6:1370-9. https://doi.org/10.1021/acssy nbio.7b00001.

119. Norred SE, Caveney PM, Retterer ST, Boreyko JB, Fowlkes JD, Collier CP, Simpson ML. Sealable femtoliter chamber arrays for cell-free biology. J Vis Exp. 2015;11:52616.

120. Contreras-Llano LE, Tan C. High-throughput screening of biomolecules using cell-free gene expression systems. Synth Biol. 2018. https://doi.org/10.1093/synbio/ysy012.

121. Axup JY, Bajjuri KM, Ritland M, Hutchins BM, Kim CH, Kazane SA, et al. Synthesis of site-specific antibody-drug conjugates using unnatural amino acids. Proc Natl Acad Sci USA. 2012;109:16101-6.

122. Strop P, Liu SH, Dorywalska M, Delaria K, Dushin RG, Tran TT, et al. Location matters: site of conjugation modulates stability and pharmacokinetics of antibody drug conjugates. Chem Biol. 2013;20:161-7.

123. Zimmerman ES, Heibeck TH, Gill A, Li X, Murray CJ, Madlansacay MR, et al. Production of site-specific antibody-drug conjugates using optimized non-natural amino acids in a cell-free expression system. Bioconjug Chem. 2014;25:351-61. 
124. Kontermann RE. Dual targeting strategies with bispecific antibodies. MAbs. 2012;4:182-97.

125. Xu Y, Lee J, Tran C, Heibeck TH, Wang WD, Yang J, et al. Production of bispecific antibodies in "knobs-into-holes" using a cell-free expression system. MAbs. 2015;7:231-42.

126. He W, Felderman M, Evans AC, Geng J, Homan D, Bourguet F, et al. Cell-free production of a functional oligomeric form of a Chlamydia major outer-membrane protein (MOMP) for vaccine development. J Biol Chem. 2017;292:15121-32.

127. Pichichero ME. Protein carriers of conjugate vaccines: characteristics, development, and clinical trials. Human Vaccines Immunother. 2013;9:2505-23. https://doi.org/10.4161/hv.26109.

128. Zichel R, Mimran A, Keren A, Barnea A, Steinberger-Levy I, Marcus D, et al. Efficacy of a potential trivalent vaccine based on $\mathrm{Hc}$ fragments of botulinum toxins $\mathrm{A}, \mathrm{B}$, and $\mathrm{E}$ produced in a cellfree expression system. Clin Vaccine Immunol. 2010;17:784-92.

129. Yadavalli R, Sam-Yellowe T. HeLa based cell free expression systems for expression of plasmodium rhoptry proteins. J Vis Exp. 2015;10:52772.

130. Ito D, Hasegawa T, Miura K, Yamasaki T, Arumugam TU, Thongkukiatkul A, et al. RALP1 is a rhoptry neck erythrocytebinding protein of Plasmodium falciparum merozoites and a potential blood-stage vaccine candidate antigen. Infect Immun. 2013;81:4290-8.

131. Ng PP, Jia M, Patel KG, Brody JD, Swartz JR, Levy S, Levy R. A vaccine directed to $B$ cells and produced by cell-free protein synthesis generates potent antilymphoma immunity. Proc Natl Acad Sci USA. 2012;109:14526-31.

132. Kanter G, Yang J, Voloshin A, Levy S, Swartz JR, Levy R. Cellfree production of $\mathrm{scFv}$ fusion proteins: an efficient approach for personalized lymphoma vaccines. Blood. 2007;109:3393-9.

133. Nagaoka H, Sasaoka C, Yuguchi T, Kanoi BN, Ito D, Morita M, et al. PfMSA180 is a novel Plasmodium falciparum vaccine antigen that interacts with human erythrocyte integrin associated protein (CD47). Sci Rep. 2019;9:5923. https://doi.org/10.1038/ s41598-019-42366-9.

134. Morita M, Nagaoka H, Ntege EH, Kanoi BN, Ito D, Nakata T, et al. PV1, a novel Plasmodium falciparum merozoite dense granule protein, interacts with exported protein in infected erythrocytes. Sci Rep. 2018;8:3696. https://doi.org/10.1038/s4159 8-018-22026-0.

135. Tohmoto T, Takashima E, Takeo S, Morita M, Nagaoka H, Udomsangpetch R, et al. Anti-MSP11 IgG inhibits Plasmodium falciparum merozoite invasion into erythrocytes in vitro. Parasitol Int. 2019;69:25-9.

136. Ito D, Takashima E, Yamasaki T, Hatano S, Hasegawa T, Miura $\mathrm{K}$, et al. Antibodies against a Plasmodium falciparum RON12 inhibit merozoite invasion into erythrocytes. Parasitol Int. 2019;68:87-91.

137. Ntege EH, Arisue N, Ito D, Hasegawa T, Palacpac NMQ, Egwang TG, et al. Identification of Plasmodium falciparum reticulocyte binding protein homologue 5-interacting protein, PfRipr, as a highly conserved blood-stage malaria vaccine candidate. Vaccine. 2016;34:5612-22.

138. Iriko H, Ishino T, Otsuki H, Ito D, Tachibana M, Torii M, Tsuboi T. Plasmodium falciparum Exported Protein 1 is localized to dense granules in merozoites. Parasitol Int. 2018;67:637-9.

139. Tsuboi T, Takeo S, Iriko H, Jin L, Tsuchimochi M, Matsuda S, et al. Wheat germ cell-free system-based production of malaria proteins for discovery of novel vaccine candidates. Infect Immun. 2008;76:1702-8.

140. Cheng Y, Wang B, Lu F, Han J-H, Ahmed MA, Han E-T. Immunological characterization of Plasmodium vivax Pv32, a novel predicted GPI-anchored merozoite surface protein. Malaria J. 2018;17:273. https://doi.org/10.1186/s12936-018-2401-7.
141. Lu Y, Chan W, Ko BY, VanLang CC, Swartz JR. Assessing sequence plasticity of a virus-like nanoparticle by evolution toward a versatile scaffold for vaccines and drug delivery. Proc Natl Acad Sci USA. 2015;112:12360-5.

142. Kapoor N, Vanjak I, Rozzelle J, Berges A, Chan W, Yin G, et al. Malaria derived glycosylphosphatidylinositol anchor enhances anti-Pfs 25 functional antibodies that block malaria transmission. Biochemistry. 2018;57:516-9.

143. Changrob S, Han J-H, Ha K-S, Park WS, Hong S-H, Chootong P, Han E-T. Immunogenicity of glycosylphosphatidylinositolanchored micronemal antigen in natural Plasmodium vivax exposure. Malaria Journal. 2017;16:348. https://doi.org/10.1186/ s12936-017-1967-9.

144. Matsunaga S, Kawakami S, Matsuo I, Okayama A, Tsukagoshi $\mathrm{H}$, Kudoh A, et al. Wheat germ cell-free system-based production of hemagglutinin-neuraminidase glycoprotein of human parainfluenza virus type 3 for generation and characterization of monoclonal antibody. Front Microbiol. 2014;5:2014.

145. Hashimoto Y, Zhou W, Hamauchi K, Shirakura K, Doi T, Yagi K, et al. Engineered membrane protein antigens successfully induce antibodies against extracellular regions of claudin-5. Sci Rep. 2018;8:8383. https://doi.org/10.1038/s41598-018-26560-9.

146. KIRK CG. Toy building set.

147. Jewett MC, Stark JC, Delisa MP, Jaroentomeechai T. Method for rapid in vitro synthesis of bioconjugate vaccines via recombinant production of $N$-glycosylated proteins in prokaryotic cell lysates.

148. Jennings GT, Bachmann MF. Immunodrugs: therapeutic VLPbased vaccines for chronic diseases. Annu Rev Pharmacol Toxicol. 2009;49:303-26.

149. Masuda T, Lefevre I, Mendelman P, Sherwood J, Bizjajeva S, Borkowski A. 2276. Immunogenicity of takedas bivalent viruslike particle (VLP) norovirus vaccine (NoV) candidate in children from 6 months up to 4 years of age. Open Forum Infect Dis. 2018;5:S674. https://doi.org/10.1093/ofid/ofy210.1929.

150. Sheng J, Lei S, Yuan L, Feng X. Cell-free protein synthesis of norovirus virus-like particles. RSC Adv. 2017;7:28837-40. https ://doi.org/10.1039/c7ra03742b.

151. Jin X, Kightlinger W, Kwon Y-C, Hong SH. Rapid production and characterization of antimicrobial colicins using Escherichia coli-based cell-free protein synthesis. Synth Biol. 2018. https:// doi.org/10.1093/synbio/ysy004.

152. Zharkova MS, Orlov DS, Golubeva OY, Chakchir OB, Eliseev IE, Grinchuk TM, Shamova OV. Application of antimicrobial peptides of the innate immune system in combination with conventional antibiotics - a novel way to combat antibiotic resistance? Front Cell Infect Microbiol. 2019. https://doi.org/10.3389/ fcimb.2019.00128.

153. Cui Z, Mureev S, Polinkovsky ME, Tnimov Z, Guo Z, Durek $\mathrm{T}$, et al. Combining sense and nonsense codon reassignment for site-selective protein modification with unnatural amino acids. ACS Synth Biol. 2017;6:535-44. https://doi.org/10.1021/acssy nbio.6b00245.

154. Oza JP, Aerni HR, Pirman NL, Barber KW, ter Haar CM, Rogulina S, et al. Robust production of recombinant phosphoproteins using cell-free protein synthesis. Nat Commun. 2015;6:8168. https://doi.org/10.1038/ncomms9168.

155. Merk H, Rues RB, Gless C, Beyer K, Dong F, Dotsch V, et al. Biosynthesis of membrane dependent proteins in insect cell lysates: identification of limiting parameters for folding and processing. Biol Chem. 2015;396:1097-107.

156. Fenz SF, Sachse R, Schmidt T, Kubick S. Cell-free synthesis of membrane proteins: tailored cell models out of microsomes. Biochim Biophys Acta. 2014;2014:1382-8.

157. Jewett MC, Anderson MJ, Stark JC, Hodgman CE. Methods for activating natural energy metabolism for improving yeast cellfree protein synthesis: 15/639,364 2017: Google Patents. 
158. Silverman AD, Karim AS, Jewett MC. Cell-free gene expression: an expanded repertoire of applications. Nat Rev Genet. 2020;21:151-70. https://doi.org/10.1038/s41576-019-0186-3.

159. Calhoun KA, Swartz JR. An economical method for cell-free protein synthesis using glucose and nucleoside monophosphates. Biotechnol Prog. 2005;21:1146-53. https://doi.org/10.1021/ bp050052y.
160. Voyvodic PL, Bonnet J. Cell-free biosensors for biomedical applications. Curr Opin Biomed Eng. 2020;13:9-15. https://doi. org/10.1016/j.cobme.2019.08.005. 